\title{
34. PROVENANCE AND DEPOSITION OF LOWER CRETACEOUS TURBIDITE SANDS AT DEEP SEA DRILLING PROJECT SITE 603, LOWER CONTINENTAL RISE OFF NORTH CAROLINA ${ }^{1}$
}

\author{
Mary Anne Holmes, James R. Breza, and Sherwood W. Wise, Jr., Department of Geology, \\ Florida State University ${ }^{2}$
}

\begin{abstract}
During the drilling of Hole 603B on Deep Sea Drilling Project Leg 93, an unexpected series of sand-, silt-, and claystone turbidites was encountered from Cores 603B-45 through -76 (1224-1512 m sub-bottom depth). Complete and truncated Bouma sequences were observed, some indicating deposition by debris flows. Sand emplacement culminated with the deposition of a 30-m-thick, unconsolidated sand unit (Cores 603B-48 through -45).

The purpose of this preliminary study is to determine the nature of the heavy mineral suites of this sediment in order to make tentative correlations with onshore equivalents. The heavy mineralogy of Lower Cretaceous North American mid-Atlantic coastal plain sediment has been extensively studied. This sediment is classified as the Potomac Group, which has a varied heavy mineral suite in its lower part (Patuxent Formation), and a limited suite in its upper part (Patapsco Formation). The results of this study reveal a similar trend in the heavy mineral suites of sediment in Hole 603B. Hauterivian through lower Barremian sediment has a heavy mineral suite that is dominated by zircon, apatite, and garnet, with minor amounts of staurolite and kyanite. Beginning in the mid-Barremian, a new source of sediment becomes dominant, one which supplies an epidote-rich heavy mineral suite. The results of the textural analyses show that average grain size of the light mineral fraction increases upsection, whereas sorting decreases. The epidote-rich source may have delivered sediment with a slightly coarser mean grain size. This sediment may represent a more direct continental input at times of maximum turbidite activity (mid-Barremian) and during deposition of the upper, unconsolidated sand unit.
\end{abstract}

\section{INTRODUCTION}

Deep Sea Drilling Project reentry Hole 603B was drilled at $35^{\circ} 29.71^{\prime} \mathrm{N}, 70^{\circ} 01.71^{\prime} \mathrm{W}$ on the lower continental rise $270 \mathrm{mi}$. (435 km) east of Cape Hatteras, North Carolina, in $4642.5 \mathrm{~m}$ of water (Fig. 1). The lower portion of the hole was cored continuously through the Cretaceous section (Fig. 2) where, quite unexpectedly, a series of Lower Cretaceous coarse-grained turbidites of a deep-sea fan complex were encountered (Cores 603B45 to -73 ). The sand turbidites are interbedded with gray laminated nannofossil marlstone, white bioturbated limestone, and black carbonaceous claystone turbidites (Fig. 3 ). This sequence constitutes approximately $268 \mathrm{~m}$ of the section. This chapter offers a preliminary analysis of the mineralogy and texture of the turbidite sand units, commenting on their possible mineral provenance and correlation with onshore units. In particular, the heavy mineral composition of the sand fraction and the stratigraphic distribution of heavy minerals within the section are described for 27 samples from Cores 603B-73 to -45 . In addition, textural analyses of the light mineral sand fraction for 24 samples from sand turbidites are provided.

\section{LITHOSTRATIGRAPHY}

In Hole 603B, local lithostratigraphic Unit V consists of a $30-\mathrm{m}$ unnamed sand unit overlying $330 \mathrm{~m}$ of upper

\footnotetext{
${ }^{1}$ van Hinte, J. E., Wise, S. W., Jr., et al., Init. Repts. DSDP, 93: Washington (U.S. Govt, Printing Office).

2 Addresses (Holmes, present address) Geology Dept., University of Nebraska-Lincoln, Lincoln, NE 68588-0340; (Breza and Wise) Dept. of Geology, Florida State University, Tallahassee, FL 32306.
}

Berriasian-Aptian sandstone to claystone turbidites, interbedded with nannofossil marlstone and limestone. Excluding the topmost sand unit, Unit V is essentially equivalent to the Blake-Bahama Formation of Jansa et al. (1979). This unit is distinguished from the overlying lithostratigraphic Unit IV by the presence of abundant calcareous nannofossils. It is divided into two subunits based on the presence or absence of turbidites. Subunit VA, which is the focus of this study, includes the upper $30 \mathrm{~m}$ of largely unconsolidated sand, and abundant clay-, silt-, and sandstone turbidites and debris flows below. There are two types of turbidites distinguished by texture: siltstone-sandstone, and organic-matter-rich claystone. The presence of intermediate types and complete sandstone to claystone graded sequences indicates that the two textural types may be genetically related. Subunit VB is composed exclusively of in situ pelagic carbonates.

The silt- and sandstone turbidites first appear in the Valanginian (Core 603B-73), reach a peak in the Barremian (Core 603B-56), and culminate with the emplacement of a massive, poorly consolidated sand sequence that spans the Barremian/Aptian boundary (Cores 603B48 to -45 ). Nearly all of the sediment recovered from Cores $603 \mathrm{~B}-46$ and -45 consists of drilling-disturbed, coarse, loose sand with shallow-water shell fragments. From Cores $603 \mathrm{~B}-71$ to -48 , individual sandstone-siltstone turbidites range up to $2 \mathrm{~m}$ in thickness and are dominated by subangular quartz with abundant feldspar, mica, heavy minerals, opaques, wood fragments (locally up to $20 \%$ ), glauconite, and shallow-water bioclastics. The sand units are poorly cemented except for the base of certain calcite-cemented, matrix-free sand beds that overlie limestone. For example, in Figure 3, the whitish 


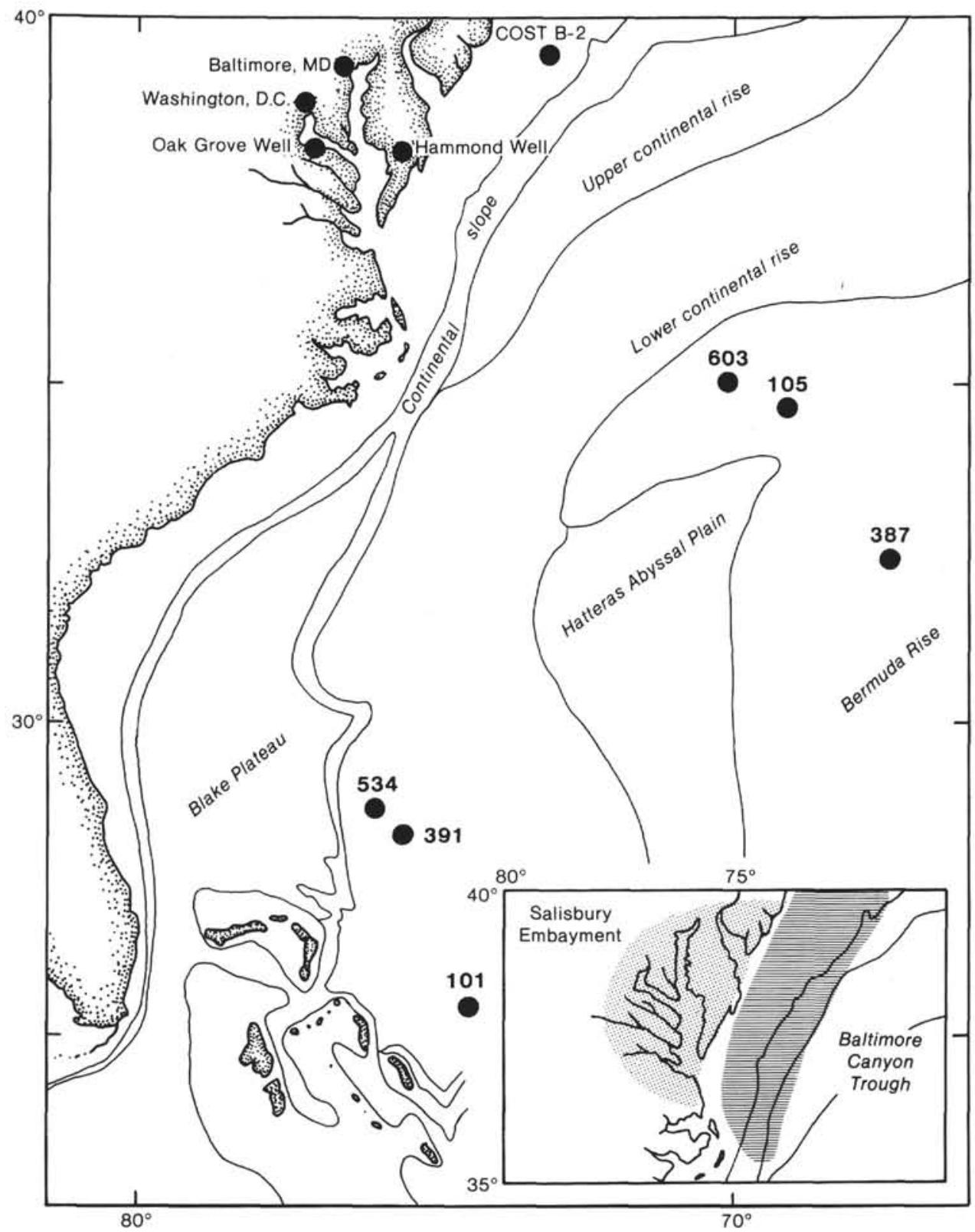

Figure 1. Locations of sites and structural elements in the study area. Insert shows outline of Salisbury Embayment and Baltimore Canyon Trough.

material in Section 603B-65-2 (between 36 and $43 \mathrm{~cm}$ ) is calcite-cemented. However, most of the sand units can be split under the pressure of a fingernail. Collectively, these turbidites exhibit the entire range of Bouma divisions, but the basal divisions $\left(\mathrm{T}_{\mathrm{a}}\right.$ to $\left.\mathrm{T}_{\mathrm{c}}\right)$ are dominant (Site 603 report, this volume). Apparently Hole 603B intersected a complex of one or more deep-sea fans that perhaps forms part of a Lower Cretaceous apron of clastic-rich sediments along the lower continental margin of eastern North America (Leg 93 Staff, 1983; van Hinte, Wise, et al., 1985).

Black, carbonaceous claystone turbidites first appear in the Valanginian, Core 603B-76-1. In the interval between Cores 603B-71 and -49, these units may appear as Bouma $T_{d-e}$ divisions overlying Bouma $T_{a-b}$ or Bouma
$\mathrm{T}_{\mathrm{b}}$ divisions (Sarti and von Rad, this volume). The latter two relationships indicate that these two turbidite types may be genetically related. However, lower levels of terrestrial organic matter in claystone turbidites may indicate that the major source material for these units was hemipelagic slope deposits.

\section{PREVIOUS WORK IN THE STUDY AREA}

\section{North American Basin: Turbidite Sequences}

Deep Sea Drilling Project Site 534 in the Blake-Bahama Basin (Fig. 1) is the only other location in the North American Basin where Lower Cretaceous clay and sand turbidites have been encountered. Robertson and Bliefnick (1983) distinguished these two types of turbidites 


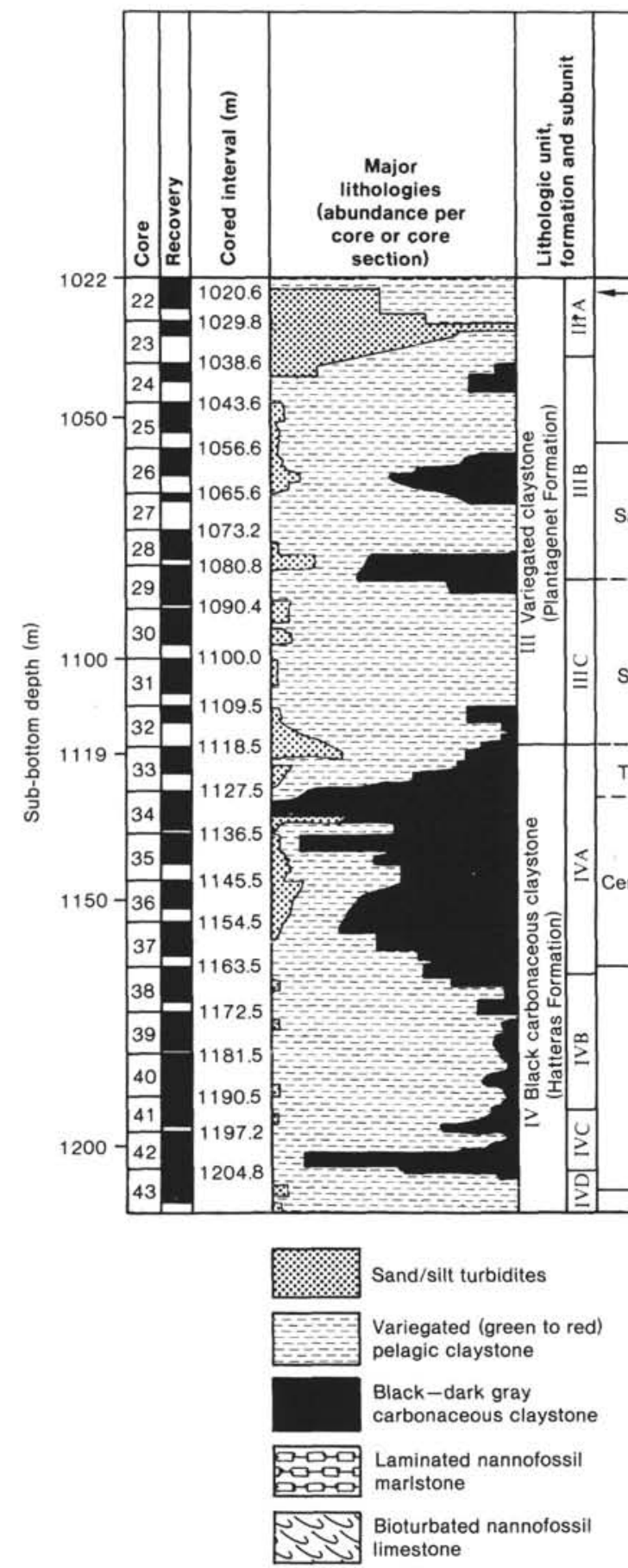

Albian

Figure 2. Columnar section of the Cretaceous interval of Hole 603B.

on the basis of texture and nannofossil content. The nannofossil-rich claystone turbidites first appear in lower Berriasian sediment as thin (up to $3.5 \mathrm{~cm}$ ) units. They increase in abundance, thickness, and organic matter content upsection until their phase of maximum development at the Valanginian/Hauterivian boundary. There,

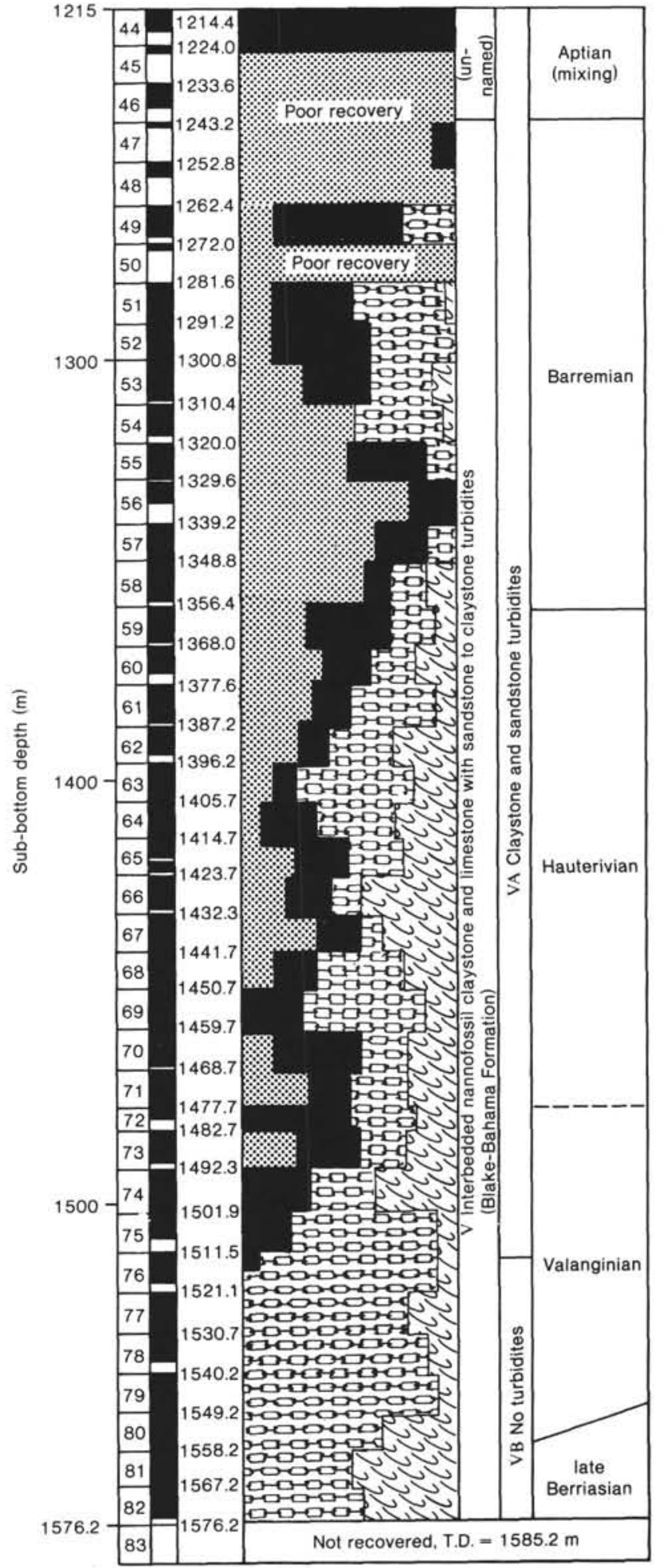

maximum bed thickness is $50 \mathrm{~cm}$, and individual units show grading and ripple lamination. The upper few centimeters are commonly bioturbated with Chrondritestype and other small burrows. Beginning in the lower Valanginian, these turbidites become intercalated with redeposited siliciclastics and carbonate clastics. The re- 


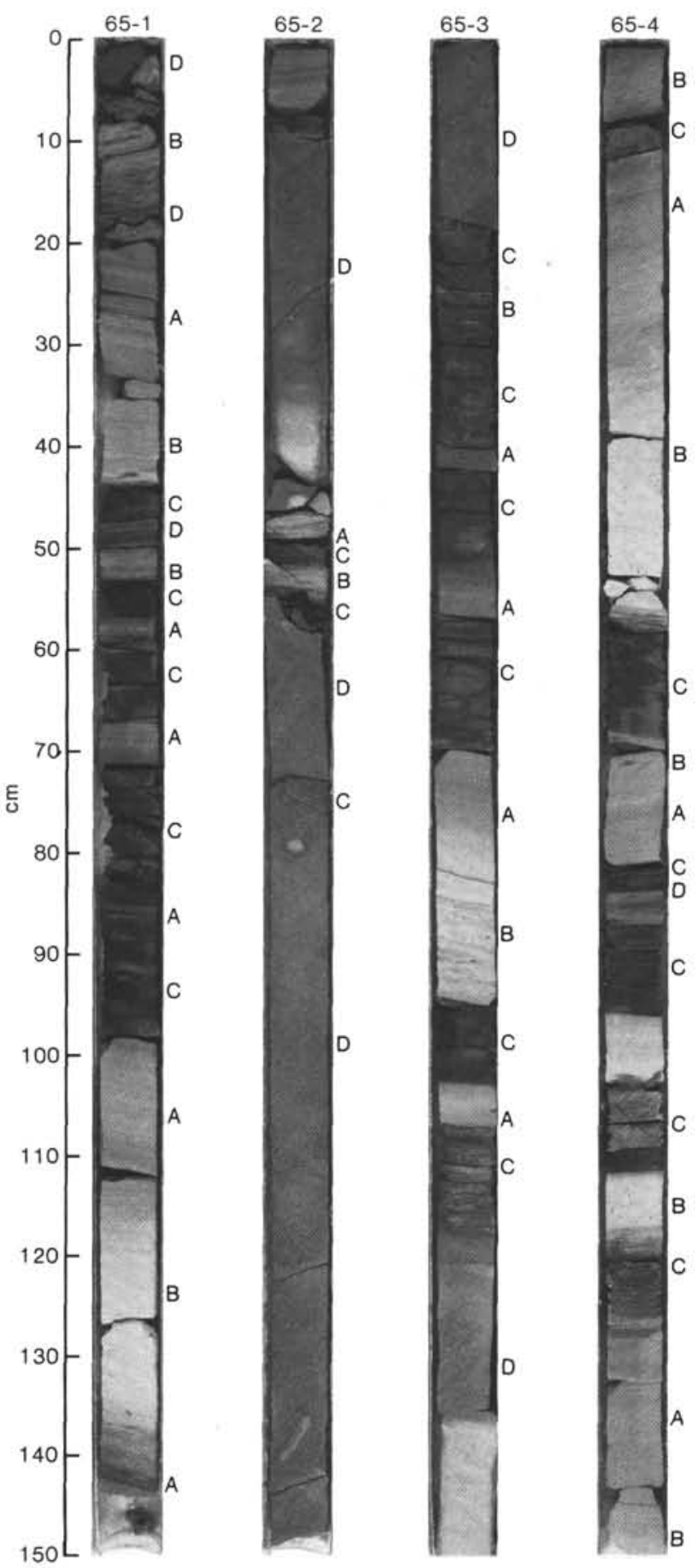

Figure 3. Core 603B-65 (1414.7-1423.7 m) from lithostratigraphic Unit VA (Blake-Bahama Formation, Valanginian-Aptian). A indicates gray laminated marlstone, and B indicates white bioturbated limestone cycles, interrupted by black carbonaceous claystone turbidites (C) and terrigenous sandstone turbidites (D). The sandstone bed spanning Sections 603B-65-2 and 603B-65-3 is $90 \mathrm{~cm}$ thick (from van Hinte et al., 1985),

deposited clastics first appear as thin, graded, siltstone partings (Core 534A-75). At their peak development in Core 534A-58, this sandstone closely resembles that at Site 603 . In this interval, individual units range up to 40 $\mathrm{cm}$ in thickness, are graded, and show plane and ripple lamination (Robertson and Bliefnick, 1983, fig. 14A).
On our examination of Core $534 \mathrm{~A}-58$, we noted that the sandstone was sufficiently friable to be split under the pressure of a fingernail. All Bouma divisions are present, but divisions $\mathrm{T}_{\mathrm{b}-\mathrm{d}}$ predominate. In addition, there are well-developed, convolute laminations and chaotic arrangements of angular, poorly sorted, matrix-supported grains characteristic of some debris flows (Robertson and Bliefnick, 1983).

Robertson and Bliefnick (1983) reported that the redeposited clastics contain variable amounts of shallow-water carbonate and terrigenous clastic material. Because of its southerly location, Site 534 turbidites have more carbonate than those at Site 603. According to Robertson and Bliefnick (1983), most of the sand units at Site 534 are dominated by quartz. Mica is subordinate along with other terrigenous grains, particularly in the upper Valanginian to Hauterivian interval (below Core 534A-60). Typical thin sections of these siliciclastic units contain silt-sized quartz, plagioclase, muscovite, biotite, orthoclase, chlorite, and minor hornblende, in decreasing order of abundance. Heavy minerals are minor components and include epidote, zircon, and tourmaline. Robertson and Bliefnick (1983) reported that the coarser-grained sand turbidites contain, in decreasing order of abundance, quartz, fresh plagioclase, polycrystalline quartz, muscovite, biotite, microcline perthite, and opaque oxides (pyrite) (see their fig. 16 for a summary of Lower Cretaceous lithologies examined with the optical microscope).

The claystone turbidites probably originated as upper continental rise deposits that were subsequently redeposited by turbidity currents (Robertson and Bliefnick, 1983). The silt and sand turbidites originated as deltaic and shelf deposits, which bypassed the upper continental rise by some conduit such as a submarine canyon (Robertson and Bliefnick, 1983).

\section{Central Atlantic Coastal Plain and Continental Shelf: Lithostratigraphy}

Onshore, the Lower Cretaceous is represented by the Potomac Group that has been extensively studied in the Salisbury Embayment (Fig. 1) by Glaser (1969). The following discussion is derived from his report. The Potomac Group units unconformably overlie Precambrian to Paleozoic igneous and metamorphic rocks in some places, and Triassic sedimentary or mafic igneous rocks in others. The Potomac Group represents the subaerial portions of extensive Lower Cretaceous deltas and, as such, contains fluvial as well as deltaic facies. In the type locality, between Baltimore and Washington, D.C. (Fig. 1), the Potomac Group can be divided into three formations: the lowermost Patuxent Formation, the Arundel Clay, and the uppermost Patapsco Formation. The presence of the Arundel Clay in this area allows for the differentiation, but pronounced lateral variation within the Potomac Group makes its subdivision outside the type area difficult. The terms "Patuxent Formation" and "Patapsco Formation" will be used here instead of "lower Potomac Group" and "upper Potomac Group."

The subsurface Waste Gate Formation is the lowermost unit of the Potomac Group and was recently pro- 
posed as a formal stratigraphic unit by Hansen (1982). Hansen (1984) reported that the self-potential (S.P.) signatures of the Waste Gate Formation at its type locality (Ohio Oil Company No. 1 Hammond Well, near Salisbury, Maryland, Fig. 1) suggest braided or stacked sand channel deposition by currents of fairly high energy. Glaser (1969) proposed a similar mode of deposition for overlying Patuxent units while noting that Patapsco units were probably deposited by slower, lower-gradient, meandering streams. Glaser (1969) emphasized the importance of flood events in the deposition of all Potomac Group units. The ages of these units have not been precisely delineated because of the paucity of biostratigraphic markers. Hansen (1984) reported that the Waste Gate Formation was dated as probably Berriasian to Hauterivian(?) in age, although the uppermost beds may be as young as early Barremian. The studies of Doyle and Robbins (1977) and Habib (1977) indicate that Patuxent units may be latest Hauterivian through Barremian, or possibly early Aptian, whereas Patapsco units appear to be Albian.

Lower Cretaceous shelf sediment from the Baltimore Canyon Trough has been described by Libby-French (1984). The following discussion is derived from her study. Libby-French (1984) made tentative correlations of formal Scotian Shelf stratigraphic units to sediment in the Baltimore Canyon Trough. Consequently the term "equivalent" is used here instead of more formal stratigraphical terms. Shelf equivalents of the Potomac Group in the Baltimore Canyon Trough represent lower delta-plain and delta-front sand and shale (Libby-French, 1984). These sediments comprise the underlying Missisauga equivalent and the overlying Logan Canyon equivalent, which in the Scotian Basin form part of the Nova Scotia Group. The offshore equivalent to these are the underlying Verrill Canyon equivalent, the Naskapi Shale equivalent, and the overlying shaly Dawson Canyon equivalent. In some places the Naskapi Shale separates the Missisauga from the Logan Canyon equivalent. The shale units represent pro-delta muds; the Missisauga and Logan Canyon sands represent progradation of the delta front. Libby-French (1984) noted the presence of thicker-bedded channel sandstone in Missisauga equivalent units in northern well sites in the Baltimore Canyon Trough, indicating a northern source for this sediment. Libby-French (1984) reported that ages are difficult to assign to these sediments because of a paucity of biostratigraphic markers. The Missisauga may be as old as Neocomian and as young as Albian, the Naskapi may be as old as Aptian and as young as Albian, and the Logan Canyon may be as old as Aptian and as young as Cenomanian.

\section{Central Atlantic Coastal Plain and Continental Shelf: Heavy Mineral Studies}

No heavy mineral studies per se have been conducted on material from the North American Basin or slope. Several studies have been carried out on outcrop and subcrop material from the Atlantic coastal plain, and one study has been conducted on North American outer continental shelf material. These studies are summarized in Table 1. Anderson (1948, in Groot, 1955) undertook the first detailed heavy mineral study of Lower Cretaceous coastal plain sediments. He described the Patuxent Formation in the Hammond Well (Fig. 1) as a garnet-staurolite-zircon zone. The Arundel-Patapsco (undifferentiated) Formation is characterized by the abrupt appearance of abundant epidote and a marked decrease in staurolite level. Groot (1955) studied Anderson's data and noted that the Patapsco-Arundel unit contains relatively thin sand beds characterized by abundant zircon with minor amounts of staurolite, tourmaline, and rutile. These units alternate with the more dominant, thickerbedded sand beds that contain abundant epidote and little or no staurolite. Groot's explanation for this phenomenon is that two different source areas contributed sediment to this site: the Piedmont area to the west or southwest of the Hammond Well contributed the epidote-rich suite, and the Piedmont area to the northwest of the well contributed the zircon-rich suite (1955).

A detailed examination of the heavy mineral suites for Cretaceous sediments from northern Delaware is provided by Groot (1955). The northern Delaware localities that Groot examined are northeast of Baltimore (Fig. 1). He noted that the Patuxent Formation cannot be distinguished from the lithologically similar Patapsco Formation because of the absence of the Arundel Clay in this area. However, he was able to distinguish two heavy mineral zones in these sediments that correlate to the Patuxent and Patapsco Formations. These zones are consistent over a wide area and can be used to distinguish the two formations. In this study Groot described the $\mathrm{Pa}$ tuxent zone as staurolite-kyanite-tourmaline-zircon (see Table 1 for percentages). These minerals distinguish the Patuxent zone from all other units studied, and do not necessarily correspond to the most abundant minerals present.

The Patapsco zone is characterized by Groot (1955) as tourmaline-zircon-rutile with abundant alterites (Table 1). Groot (1955) described this suite as impoverished relative to that of the Patuxent. The dominance of the suite by the more stable minerals-zircon, tourmaline, and rutile-indicates prolonged and intensive weathering in the source area. This contrasts with the more varied suite of the Patuxent, indicating that weathering intensity increased and/or relief of the source area decreased between Patuxent and Patapsco time. Additional evidence for this conclusion arises from the worn and pitted appearance of sporadically occurring, less stable minerals, such as garnet, staurolite, sillimanite, kyanite, and epidote. Groot (1955) concluded that the sources of the clasts for the Potomac Group were metamorphic and igneous rocks of the Piedmont Province, with smaller contributions from Paleozoic sedimentary rock of the Appalachians. More specifically, some tourmaline grains had carbonaceous inclusions, indicating the grains came from carbonaceous phyllites and slates. Other tourmaline and zircon grains had liquid and gas inclusions, indicating an additional acid igneous source.

In a more detailed study of tourmaline grains in these sediments, Groot (1955) found that these increase in roundness in younger sediments. $\mathrm{He}$ attributes this to 
Table 1. Summary from north to south of heavy mineral studies of mid-Atlantic coastal plain and outer continental shelf (OCS) sediment.

\begin{tabular}{|c|c|c|c|c|c|c|}
\hline \multirow[b]{2}{*}{ Formation } & \multicolumn{5}{|c|}{ Coastal plain } & \multirow{2}{*}{$\frac{\text { OCS }}{\text { COST B-2 Welle }} \underset{(\%)}{(\%)}$} \\
\hline & $\begin{array}{c}\text { Northern } \\
\text { Delaware } \\
(\%)\end{array}$ & $\begin{array}{c}\text { Hammond Well, } \\
\text { Maryland }\end{array}$ & $\begin{array}{c}\text { Maryland } \\
\text {-Delaware } \\
(\%)\end{array}$ & $\begin{array}{l}\text { "Northern" } \\
\text { Virginiac } \\
(\%)\end{array}$ & $\begin{array}{l}\text { Oak Grove Well } \\
\text { Virginiad } \\
(\%)\end{array}$ & \\
\hline Patapsco & $\begin{array}{l}\text { Alterites (34) } \\
\text { Zircon (33) } \\
\text { Opaques (20) } \\
\text { Rutile (15) } \\
\text { Anatase (4) } \\
\text { Staurolite (2) }\end{array}$ & $\begin{array}{l}\text { Thick-bedded sand with abundant } \\
\text { epidote alternating with } \\
\text { thin-bedded sand with } \\
\text { abundant zircon } \\
\text { Sparse staurolite }\end{array}$ & $\begin{array}{l}\text { Tourmaline (47) } \\
\text { Zircon (47) } \\
\text { Altered (10) } \\
\text { Staurolite (8) } \\
\text { Rutile (2) }\end{array}$ & $\begin{array}{l}\text { Zircon (93) } \\
\text { Staurolite (2) } \\
\text { Tourmaline (1) }\end{array}$ & $\begin{array}{l}\text { Zircon } \\
\text { Tourmaline }\end{array}$ & $\begin{array}{l}\text { Garnet (22) } \\
\text { Chlorite (20) } \\
\text { Tourmaline (19) } \\
\text { Chlorite (13) } \\
\text { Zircon (10) } \\
\text { Epidote (9) }\end{array}$ \\
\hline Patuxent & $\begin{array}{l}\text { Staurolite (50) } \\
\text { Opaques (33) } \\
\text { Tourmaline (13) } \\
\text { Zircon (12) } \\
\text { Alterites (11) } \\
\text { Kyanite (5) } \\
\text { Rutile (5) } \\
\text { Anatase (2) }\end{array}$ & Staurolite $>$ garnet, zircon & $\begin{array}{l}\text { Staurolite (34) } \\
\text { Zircon (29) } \\
\text { Tourmaline (20) } \\
\text { Kyanite (8) } \\
\text { Altered minerals (5) }\end{array}$ & $\begin{array}{l}\text { Zircon (91) } \\
\text { Altered minerals (4) } \\
\text { Staurolite (3) } \\
\text { Tourmaline (2) }\end{array}$ & $\begin{array}{l}\text { Zircon } \\
\text { Staurolite } \\
\text { Garnet } \\
\text { Apatite ( } \leq \text { ) } \\
\text { Glauconite (10) }\end{array}$ & $\begin{array}{l}\text { Staurolite (5) } \\
\text { Sphene (5) }\end{array}$ \\
\hline
\end{tabular}

a Groot, 1955.

b Anderson, 1948, in Groot, 1955.

c Glaser, 1969.

d Reinhardt et al., 1980.

e Smith, 1980.

the oldest deposits being first-cycle sediment and the younger deposits (Patapsco and younger) second- or even third-cycle. The Patuxent may have served as a source of the more weathered, rounded clasts in Patapsco sediment. These findings correspond with the changes in stream character between these units as noted by Glaser (1969, see previous discussion). The Patapsco streams were slower and of lower gradient than those of the Patuxent, indicating a possible leveling of source area and/or a rise in sea level prior to or during Patapsco deposition. This resulted in lower rates of erosion and thus more in situ weathering. Vail et al. (1977) show a sea level rise in the Albian that may account for more sluggish streams during Patapsco deposition.

A more recent study of the heavy mineral suites of Lower Cretaceous sediment of the Salisbury Embayment is provided by Glaser (1969). He found considerable alongstrike variation in light as well as heavy mineral suites. In Maryland and Delaware he found that the heavy mineral suites of the Patuxent Formation were mixed, dominated by staurolite, zircon, and tourmaline (Table 1). These results agree with those of Anderson (1948) and Groot (1955) when opaques are not considered. South of Washington, D.C. (Fig. 1, see also "Northern" Virginia column in Table 1), the suites of Patuxent sediment are dominated by zircon $(91 \%)$; tourmaline, staurolite, and altered minerals were usually the only other minerals present (Table 1). Glaser (1969) examined two samples from southern Virginia that show a marked increase in staurolite ( 25 and $73 \%$ ) and kyanite (9 and $17 \%$ ) relative to the northern Virginia samples. Glaser (1969) accounted for these variations by noting that the nature of recent Piedmont and Blue Ridge outcrops changes along strike. In the northern part of the embayment (Maryland and Delaware) there are more metamorphic than igneous rocks exposed, while the reverse is true to the south (in Virginia). Potomac Group sediment from northern Virginia is also richer in microcline than that of Mary- land and Delaware. Along with the zircon-dominated heavy mineral suite, this indicates that local acid igneous rocks were the major source of Patuxent sediment in northern Virginia (Glaser, 1969). Glaser (1969) proposed two sources for the Patuxent Formation from mineralogic data and crossbed directions. A mainly granitic source area from the south contributed sand eastward and northeastward into the Embayment. This source was characterized by a low staurolite-kyanite-tourmaline content and high feldspar. A high-grade schist source from the north contributed sand eastward and southeastward into the Embayment. This source was characterized by a high staurolite-kyanite-tourmaline content and low feldspar.

The heavy mineral suite in the Patapsco Formation in Maryland and Delaware as described by Glaser (1969) is dominated by ultrastable minerals such as zircon and tourmaline (Table 1). Other components include altered minerals, staurolite, rutile, and chloritoid and brookite. Glaser (1969) concluded that the sand of the Patapsco Formation is derived from a highly weathered Piedmont terrain and from Appalachian sandstone farther to the west. These results agree with those of Groot (1955) and Anderson (1948), indicating, again, a more highly weathered source terrain for Patapsco sediment.

Reinhardt et al. (1980) identified heavy minerals from Lower Cretaceous sediment recovered in the Oak Grove core in eastern Virginia (southeast Salisbury Embayment, Fig. 1). As in the previous studies of the Potomac Group, they found a variable suite of heavy minerals in Patuxent sediment and a more limited suite in younger sediment (Table 1). The lower, variable suite is dominated by staurolite, garnet, and zircon (percentages for these minerals were not reported). In addition, apatite may comprise up to $40 \%$ of the heavy mineral fraction. Reinhardt et al. (1980) proposed that the apatite may have been derived from the Fredericksburg Complex of igneous rocks $50 \mathrm{~km}$ west of Oak Grove. Up to $10 \%$ of the 
heavy mineral suite may consist of well-rounded, crystalline glauconite in samples from the lower $70 \mathrm{~m}$ (Barremian? and Aptian) of the core. Reinhardt et al. (1980) note that the presence of glauconite indicates a stronger marine influence on Patuxent deposition in Virginia than in sediment deposited farther north.

The upper (Patapsco) sediment at Oak Grove as described by Reinhardt et al. (1980) contains a limited suite dominated by zircon (Table 1). Staurolite, tourmaline, epidote, and garnet are present and locally common. Apatite is rare, and glauconite was not observed. No percentages for these minerals were provided by the authors. The trends as reported concur with the results of previous studies in that a more varied (Patuxent) heavy mineral suite is replaced by a more limited (Patapsco) suite. Again, a more weathered source terrain for Albian sediment is indicated.

Smith (1980) conducted a study of the heavy minerals in well cuttings from the COST B-2 Well in the North American outer continental shelf (Fig. 1). Eight samples are from Lower Cretaceous units, which compose $1230 \mathrm{~m}$ of section. The two uppermost samples are from Albian sediment (Scholle, 1977). Relative to the lower samples, these show an average decrease in garnet $(9$ and $17 \%$, average $13 \%$ ) and tourmaline (7 and $27 \%$, average $17 \%$ ). One of the Albian samples has $65 \%$ chlorite. Most notable is the minor presence in all samples of staurolite, the dominant mineral in Lower Cretaceous coastal plain suites. This difference reflects along-strike variation in source areas. The COST B-2 Well lies northeast of the Salisbury Embayment and its delta-front sediment probably had a different source from that of the Potomac Group.

Glaser (1969) and Groot (1955) discussed the possibility of intrastratal solution affecting the heavy mineral suites of Lower Cretaceous mid-Atlantic coastal plain sediment. Groot (1955) observed that the more limited Patapsco heavy mineral suite occurs in generally finergrained sediment than the more variable Patuxent suite. In addition, Patapsco sediment is underlain and overlain by sediment with much more varied heavy mineral suites. If intrastratal solution had a profound effect on these sediments, it should have removed species such as garnet, kyanite, and staurolite from coarser-grained, more matrix-free, older Patuxent sediment. The absence of apatite from Groot's (1955) study may result from his pretreatment of samples by boiling in $10 \% \mathrm{HCL} / \mathrm{HNO}_{3}$ solution. Glaser (1969) mentions no pretreatment of his samples. He does suggest that the absence of epidote in most Potomac Group outcrops may result from postdepositional loss of this mineral. His alternative hypothesis for low levels of or no epidote is that epidote may have been supplied by longshore drift of sediment derived from New England. There is some evidence for this in overlying Upper Cretaceous sediment. Here the full-suite minerals as a proportion of the total heavy mineral suite decrease from New Jersey $(\mathbf{4 5 \%})$ southward to Maryland (25\%). However, for Glaser (1969) this evidence is far from conclusive. Certainly some amount of intrastratal solution can be demonstrated to have occurred in Potomac Group sediments. This would reduce the variety of minerals present and, consequently, the amount of information we can derive from a study of the minerals left. However, the reproducibility of the observations on Atlantic coastal plain heavy mineral suites (summarized below) indicates that conclusions derived from these studies are valid.

In summary, the four studies of Potomac Group sediments show good agreement in their results (Table 1). Staurolite is generally abundant only in the lower unit and is associated with zircon. Other minerals are present in smaller amounts. Their variable levels may be explained by Glaser's (1969) and Groot's (1955) separate hypotheses of different types of source rock for these sediments. The data of Reinhardt et al. (1980) show the influence of local sources not available to the Maryland-Delaware area by the presence of apatite and hyacinth-colored zircon. The Patapsco Formation is characterized by the absence of staurolite and the presence of a more stable suite of minerals. Zircon and tourmaline are the most abundant minerals in all but Anderson's (1948, in Groot 1955) study, which is the only one to record abundant epidote. Possibly the Hammond Well had a separate local or longshore source of epidote. The Patapsco units all show an impoverishment in the heavy mineral suite, indicating a leveling of source area, more intense weathering in the source area, additional contribution of sediment from preexisting (possibly Patuxent) sediments, or some combination of these three factors.

\section{METHODS}

A total of 55 samples of varying textures were taken from turbidites recovered from Hole 603B, Cores 603B-73 through -45 (Table 2). The samples were disaggregated by soaking in distilled water for $24 \mathrm{hr}$. They were then dried, weighed, wet-sieved through a $62.5-\mu \mathrm{m}$ screen using distilled water, dried and weighed again to determine sand and silt and clay (mud) fractions. The mud fraction was saved for X-ray diffraction analysis. The sand fraction was separated into heavy and light mineral components by centrifugation at $1500 \mathrm{rpm}$ in tetrabromoform ( 2.89 specific gravity) for $15 \mathrm{~min}$., washed with wash-grade acetone, dried, and weighed to determine heavy and light mineral fractions (Table 3). Twenty-four samples (Table 4) of the light mineral fractions were sieved into 0.5- $\Phi$ intervals using an Allen-Bradley sonic sifter. Mean, standard deviation, skewness, and kurtosis were calculated using Kirkpatrick's (1982) granulometric statistical program (Table 4).

The heavy minerals were separated into two sizes. Particles less than $1.75 \Phi(>300 \mu \mathrm{m})$ consisted entirely of pyritized plant fragments, authigenic pyrite, authigenic siderite, and mica flakes. Heavy mineral grains greater than $1.75 \Phi$ and less than $4.0 \Phi(62.5-300 \mu \mathrm{m})$ were mounted in epoxy mounting medium and examined under a petrographic microscope. Twenty-nine samples were selected for grain counting. A minimum of 300 heavy mineral grains were identified and counted for each sample, using the ribbon method of counting (Galehouse, 1971). These proportions have been expressed as percentages in Table 5 . The heavy mineral assemblages listed in Table 5 do not include authigenic minerals or mica, although these were counted in this analysis. The authigenic minerals, which constituted approximately half of each sample, include pyrite, siderite, and pyritized plant and wood fragments. Mica is not included because of its variable specific gravity. Mean, standard deviation, $t$-tests, and correlation coefficients ( $r$ values) for the results were calculated using Statsoft statistical package STATS-2. Confidence levels $(C)$ for correlation coefficients were taken from Rohlf and Sokal (1969, p. 224).

\section{RESULTS}

\section{Textural Analysis of Light Mineral Sand Fraction}

The proportion of sand in the, samples examined varies from 0.4 to $86.9 \%$ and averages $48.1 \%$ (Table 2). 
Table 2. Weight percent of Lower Cretaceous sand and mud fractions, Hole 603B.

\begin{tabular}{|c|c|c|c|c|c|}
\hline $\begin{array}{l}\text { Sample } \\
\text { (Core-Section, } \\
\text { interval in } \mathrm{cm} \text { ) }\end{array}$ & $\begin{array}{l}\text { Sub-bottom } \\
\text { depth } \\
\text { (m) }\end{array}$ & $\begin{array}{c}\text { Mud } \\
(\%)\end{array}$ & $\begin{array}{l}\text { Sand } \\
(\%)\end{array}$ & Sand:mud & Textural class \\
\hline $46-2,13-15$ & 1235.0 & 13.1 . & 86.9 & 6.6 & MS \\
\hline $46-2,100-102$ & 1236.1 & 14.7 & 85.3 & 5.8 & MS \\
\hline $46-2,125-127$ & 1236.4 & 21.7 & 78.3 & 3.6 & MS \\
\hline $46-2,142-143$ & 1236.5 & 73.3 & 26.7 & 0.4 & SM \\
\hline $46-3,16-18$ & 1236.8 & 14.9 & 85.1 & 5.3 & MS \\
\hline $46-3,126-128$ & 1237.8 & 19.5 & 80.5 & 4.1 & MS \\
\hline $46-4,5-7$ & 1240.2 & 13.5 & 86.5 & 6.4 & MS \\
\hline $47-1,49-56$ & 1243.7 & 36.0 & 64.0 & 1.8 & MS \\
\hline $47-1,66-68$ & 1243.9 & 30.5 & 69.5 & 2.3 & MS \\
\hline $48-1,49-50$ & 1253.0 & 38.0 & 62.0 & 1.6 & MS \\
\hline $48-1,56-57$ & 1253.4 & 87.6 & 12.4 & 0.1 & SM \\
\hline $48-2,100-102$ & 1255.2 & 57.7 & 42.3 & 0.7 & SM \\
\hline $49-1,20-22$ & 1262.4 & 20.8 & 79.2 & 3.8 & MS \\
\hline $49-1,40-42$ & 1263.0 & 22.1 & 77.9 & 3.5 & MS \\
\hline $49-1,94-96$ & 1263.4 & 44.2 & 55.8 & 1.3 & MS \\
\hline $50-1,113-114$ & 1273.0 & 78.8 & 21.2 & 0.3 & SM \\
\hline $52-3,106-107$ & 1295.3 & 75.4 & 24.6 & 0.3 & SM \\
\hline $52-5,50-52$ & 1297.7 & 77.2 & 22.8 & 0.3 & SM \\
\hline $52-5,107-109$ & 1298.0 & 80.1 & 19.9 & 0.2 & SM \\
\hline $52-6,47-49$ & 1299.2 & 98.8 & 1.2 & 0.01 & M \\
\hline $53-3,95-96$ & 1304.8 & 99.6 & 0.4 & 0.004 & $\mathrm{M}$ \\
\hline $54-3,103-104$ & 1314.4 & 25.7 & 74.3 & 2.9 & MS \\
\hline $54-3,146-147$ & 1314.9 & 97.6 & 2.4 & 0.02 & M \\
\hline $54-4,55-56$ & 1315.5 & 48.1 & 51.9 & 1.1 & MS \\
\hline $54-4,104-105$ & 1315.9 & 42.6 & 57.4 & 1.3 & MS \\
\hline $55-3,145-147$ & 1324.5 & 89.1 & 10.9 & 0.1 & SM \\
\hline $56-2,133-135$ & 1332.4 & 39.1 & 60.9 & 1.6 & MS \\
\hline $57-3,59-61$ & 1342.8 & 46.8 & 53.2 & 1.1 & MS \\
\hline $57-4,36-37$ & 1344.1 & 48.3 & 51.7 & 1.1 & MS \\
\hline $57-4,79-81$ & 1344.5 & 85.2 & 14.8 & 0.2 & SM \\
\hline $57-4,132-133$ & 1345.0 & 38.3 & 61.7 & 1.6 & MS \\
\hline $57-5,37-38$ & 1346.0 & 32.6 & 67.4 & 2.1 & MS \\
\hline $57-5,98-100$ & 1346.2 & 53.7 & 46.3 & 0.9 & SM \\
\hline $57-5,142-144$ & 1346.6 & 80.8 & 19.2 & 0.2 & SM \\
\hline $57-6,26-27$ & 1347.0 & 61.4 & 38.6 & 0.6 & SM \\
\hline $57-6,112-113$ & 1347.8 & 41.6 & 58.4 & 1.4 & MS \\
\hline $58-1,50-51$ & 1349.3 & 37.7 & 62.3 & 1.6 & MS \\
\hline $58-2,38-39$ & 1350.7 & 24.9 & 75.1 & 3.1 & MS \\
\hline $58-2,71-72$ & 1351.0 & 64.6 & 35.4 & 0.6 & SM \\
\hline $58-3,71-72$ & 1352.5 & 29.5 & 70.5 & 2.4 & MS \\
\hline $60-1,35-37$ & 1368.4 & 54.5 & 45.5 & 0.8 & SM \\
\hline $60-2,97-99$ & 1370.5 & 31.1 & 68.9 & 2.2 & MS \\
\hline $60-3,100-102$ & 1372.0 & 35.6 & 64.4 & 1.8 & MS \\
\hline $61-1,51-52$ & 1378.0 & 70.4 & 29.6 & 0.4 & SM \\
\hline $61-2,51-52$ & 1379.6 & 71.3 & 28.7 & 0.4 & SM \\
\hline $61-6,51-52$ & 1385.2 & 74.8 & 25.2 & 0.3 & SM \\
\hline $62-2,113-114$ & 1389.4 & 60.2 & 39.8 & 0.7 & SM \\
\hline $63-7,16-17$ & 1405.3 & 39.2 & 60.8 & 1.6 & MS \\
\hline $65-2,86-87$ & 1417.0 & 45.2 & 54.8 & 1.2 & MS \\
\hline $66-5,23-24$ & 1431.7 & 30.7 & 69.3 & 2.2 & MS \\
\hline $70-2,28-29$ & 1461.3 & 87.0 & 13.0 & 0.2 & SM \\
\hline $71-1,117-118$ & 1470.0 & 39.7 & 60.3 & 1.5 & MS \\
\hline $71-3,23-24$ & 1472.0 & 58.0 & 42.0 & 0.7 & SM \\
\hline $71-3,116-117$ & 1472.9 & 76.1 & 23.9 & 0.3 & SM \\
\hline $73-2,93-94$ & 1495.1 & 76.1 & 23.9 & 0.3 & SM \\
\hline Average & & 51.91 & 48.09 & 1.59 & \\
\hline Standard deviation & & 24.67 & 75.33 & 1.64 & \\
\hline Minimum & 1235 & 13.1 & 86.9 & 0.004 & \\
\hline Maximum & 1495.1 & 99.6 & 0.4 & 6.6 & \\
\hline Count & 55 & 55 & 55 & 55 & \\
\hline
\end{tabular}

Note: $\mathrm{MS}=$ muddy sand, $\mathrm{SM}=$ sandy mud, and $\mathrm{M}=$ mud.

The weight percentages of the silt and clay fractions were not separately determined. Folk's (1980) textural classification uses the sand:mud ratio for gravelly sediment, and under this system three samples noted in Table 2 would be classified as mud ( $>90 \%$ mud). All other samples range from sandy mud (sand:mud ratio $<1$ ) to muddy sand (sand:mud ratio $>1$ ). The proportion of mud varies throughout the core and shows no regular variation with depth $(r=+0.272$, Fig. 4$)$. The samples from Core 603B-46, which contain poorly recovered homogenized, unconsolidated sand and drill biscuits, show
Table 3. Weight percent of Lower Cretaceous sand-size heavy and light minerals, Hole 603B.

\begin{tabular}{|c|c|c|c|}
\hline $\begin{array}{c}\text { Sample } \\
\text { (Core-Section, } \\
\text { interval in cm) }\end{array}$ & $\begin{array}{l}\text { Sub-bottom } \\
\text { depth } \\
\text { (m) }\end{array}$ & $\begin{array}{c}\text { Heavy } \\
(\%)\end{array}$ & $\begin{array}{c}\text { Light } \\
(\%)\end{array}$ \\
\hline $46-2,13-15$ & 1235.0 & 3.5 & 96.5 \\
\hline $46-2,100-102$ & 1236.1 & 1.9 & 98.1 \\
\hline $46-2,125-127$ & 1236.4 & 4.7 & 95.3 \\
\hline $46-2,142-143$ & 1236.5 & 5.1 & 94.9 \\
\hline $46-3,16-18$ & 1236.8 & 3.1 & 96.9 \\
\hline $46-3,126-128$ & 1237.8 & 5.8 & 94.2 \\
\hline $46-4,5-7$ & 1240.2 & 4.6 & 95.4 \\
\hline $47-1,49-56$ & 1243.7 & 2.9 & 97.1 \\
\hline $47-1,66-68$ & 1243.9 & 1.8 & 98.2 \\
\hline $48-1,49-50$ & 1253.0 & 2.5 & 97.5 \\
\hline $48-1,56-57$ & 1253.4 & 5.1 & 94.9 \\
\hline $48-2,100-102$ & 1255.2 & 6.5 & 93.5 \\
\hline $49-1,20-22$ & 1262.4 & 1.8 & 98.2 \\
\hline $49-1,40-42$ & 1263.0 & 1.8 & 98.2 \\
\hline $49-1,94-96$ & 1263.4 & 5.4 & 94.6 \\
\hline $50-1,113-114$ & 1273.0 & 5.4 & 94.6 \\
\hline $52-3,106-107$ & 1295.3 & 6.7 & 93.3 \\
\hline $52-5,50-52$ & 1297.7 & 4.2 & 95.8 \\
\hline $52-5,107-109$ & 1298.0 & 5.7 & 94.3 \\
\hline $52-6,47-49$ & 1299.2 & 12.5 & 87.5 \\
\hline $53-3,95-96$ & 1304.8 & 9.1 & 90.9 \\
\hline $54-3,103-104$ & 1314.4 & 1.8 & 98.2 \\
\hline $54-4,55-56$ & 1315.5 & 1.4 & 98.6 \\
\hline $54-4,104-105$ & 1315.9 & 1.5 & 98.5 \\
\hline $55-3,145-147$ & 1324.5 & 46.1 & 53.9 \\
\hline $56-2,133-135$ & 1332.4 & 2.0 & 98.0 \\
\hline $57-3,59-61$ & 1342.8 & 1.9 & 98.1 \\
\hline $57-4,36-37$ & 1344.1 & 1.7 & 98.3 \\
\hline $57-4,79-81$ & 1344.5 & 11.1 & 88.9 \\
\hline $57-4,132-133$ & 1345.0 & 2.1 & 97.9 \\
\hline $57-5,37-38$ & 1346.0 & 3.0 & 97.0 \\
\hline $57-5,98-100$ & 1346.2 & 1.6 & 98.4 \\
\hline $57-5,142-144$ & 1346.6 & 3.3 & 96.7 \\
\hline $57-6,26-27$ & 1347.0 & 2.4 & 97.6 \\
\hline $57-6,112-113$ & 1347.8 & 1.9 & 98.1 \\
\hline $58-1,50-51$ & 1349.3 & 2.1 & 97.9 \\
\hline $58-2,38-39$ & 1350.7 & 2.6 & 97.4 \\
\hline $58-2,71-72$ & 1351.0 & 1.7 & 98.3 \\
\hline $58-3,71-72$ & 1352.5 & 2.4 & 97.6 \\
\hline $60-1,35-37$ & 1368.4 & 1.2 & 98.8 \\
\hline $60-2,97-99$ & 1370.5 & 3.1 & 96.9 \\
\hline $61-1,51-52$ & 1378.0 & 2.8 & 97.2 \\
\hline $61-2,51-52$ & 1379.6 & 3.6 & 96.4 \\
\hline $61-6,51-52$ & 1385.2 & 2.0 & 98.0 \\
\hline $62-2,113-114$ & 1389.4 & 2.3 & 97.7 \\
\hline $63-7,16-17$ & 1405.3 & 1.5 & 98.5 \\
\hline $65-2,86-87$ & 1417.0 & 2.1 & 97.9 \\
\hline $66-5,23-24$ & 1431.7 & 1.1 & 98.9 \\
\hline $70-2,28-29$ & 1461.3 & 5.2 & 94.8 \\
\hline $71-1,117-118$ & 1470.0 & 1.1 & 98.9 \\
\hline $71-3,23-24$ & 1472.0 & 7.9 & 92.1 \\
\hline $71-3,116-117$ & 1472.9 & 3.0 & 97.0 \\
\hline $73-2,93-94$ & 1495.1 & 5.7 & 94.3 \\
\hline Average & & 3.60 & 96.4 \\
\hline Standard deviation & & 2.47 & 97.5 \\
\hline Minimum & 1235.0 & 1.1 & 98.9 \\
\hline Maximum & 1495.1 & 12.5 & 87.5 \\
\hline Count & 53 & 52 & 52 \\
\hline
\end{tabular}

the greatest amounts of sand. Percent mud is positively correlated with mean grain size of the light mineral fraction in $\phi$ units $(r=+0.619, C=99 \%)$. Thus, as the amount of mud in a sample increases, the average grain size of the light mineral fraction decreases.

The percentage of heavy minerals in the samples varies from 1.1 to $12.5 \%$, with one sample (603B-55-3, $145-147 \mathrm{~cm}$ ) having an anomalous $46.1 \%$ (Table 3). Most of this sample was composed of authigenic siderite. The 
Table 4. Textural analysis of Lower Cretaceous light mineral sand fraction, Hole 603B.

\begin{tabular}{|c|c|c|c|c|c|c|}
\hline $\begin{array}{c}\text { Sample } \\
\text { (Core-Section, } \\
\text { interval in } \mathrm{cm} \text { ) }\end{array}$ & $\begin{array}{l}\text { Sub-bottom } \\
\text { depth } \\
\text { (m) }\end{array}$ & $\begin{array}{c}\text { Textural } \\
\text { Class }\end{array}$ & $\begin{array}{c}\text { Textural } \\
\text { Mean } \\
(\phi)\end{array}$ & $\begin{array}{c}\text { Sorting } \\
(\phi)\end{array}$ & $\begin{array}{c}\text { Skewness } \\
(\phi)\end{array}$ & $\underset{(\phi)}{\text { Kurtosis }}$ \\
\hline $46-2,13-14$ & 1235.0 & MS & 2.228 & 0.907 & -0.179 & 3.329 \\
\hline $46-2,100-102$ & 1236.1 & MS & 2.45 & 0.777 & 0.919 & 2.344 \\
\hline $46-3,126-128$ & 1237.8 & MS & 2.19 & 0.928 & 0.044 & 2.759 \\
\hline $46-4,5-7$ & 1240.2 & MS & 2.01 & 0.805 & 0.228 & 3.325 \\
\hline $47-1,49-56$ & 1243.7 & MS & 3.13 & 0.727 & -0.314 & 3.455 \\
\hline $47-1,66-68$ & 1243.9 & MS & 3.041 & 0.697 & -0.119 & 2.700 \\
\hline $48-2,100-102$ & 1255.2 & SM & 2.97 & 0.861 & -0.477 & 4.047 \\
\hline $49-1,20-22$ & 1262.4 & MS & 2.96 & 0.742 & -0.459 & 4.887 \\
\hline $49-1,40-42$ & 1263.0 & MS & 3.001 & 0.631 & -0.289 & 3.918 \\
\hline $49-1,94-96$ & 1263.4 & MS & 2.02 & 0.727 & 0.157 & 3.219 \\
\hline $50-1,113-114$ & 1273.0 & SM & 3.394 & 0.755 & -0.831 & 7.979 \\
\hline $52-5,107-109$ & 1298.0 & SM & 3.140 & 0.827 & -0.609 & 4.585 \\
\hline $54-4,55-56$ & 1315.5 & MS & 3.095 & 0.662 & -0.109 & 2.704 \\
\hline $56-2,133-135$ & 1332.4 & MS & 2.816 & 0.894 & -0.376 & 3.548 \\
\hline $57-6,26-27$ & 1347.0 & SM & 3.076 & 0.726 & -0.277 & 3.083 \\
\hline $58-1,50-51$ & 1349,3 & MS & 2.527 & 0.795 & 0.082 & 2.382 \\
\hline $60-1,35-37$ & 1368.4 & SM & 3.317 & 0.651 & -0.466 & 4.618 \\
\hline $61-1,51-52$ & 1378.0 & SM & 3.226 & 0.668 & -0.288 & 2.873 \\
\hline $62-2,113-114$ & 1389.4 & SM & 3.163 & 0.678 & -0.290 & 3.023 \\
\hline $63-7,16-17$ & 1405.3 & MS & 3.172 & 0.693 & -0.247 & 3.266 \\
\hline $65-2.86-87$ & 1417.0 & MS & 3.106 & 0.709 & -0.221 & 2.878 \\
\hline $66-5,23-24$ & 1430.0 & MS & 3.049 & 0.566 & -0.033 & 2.974 \\
\hline $70-2,28-29$ & 1461.3 & SM & 3.692 & 0.441 & -0.512 & 4.316 \\
\hline $71-1,117-118$ & 1470.0 & MS & 3.511 & 0.503 & -0.405 & 3.673 \\
\hline Average & & & 2.929 & 0.724 & -0.211 & 3.579 \\
\hline Standard deviation & & & 0.447 & 0.117 & 0.338 & 1.146 \\
\hline Minimum & 1235 & & 2.01 & 0.441 & $\sim 0.831$ & 2.344 \\
\hline Maximum & 1470 & & 3.692 & 0.928 & 0.919 & 7.979 \\
\hline Count & 24 & & 24 & 24 & 24 & 24 \\
\hline
\end{tabular}

Note: $\mathrm{MS}=$ muddy sand; $\mathrm{SM}=$ sandy mud. average amount of the heavy minerals (excluding sample $603-55-3,145-147 \mathrm{~cm}$ ) is $3.6 \%$. The amount of heavy minerals in a sample shows no regular variation with depth $(r=-0.126$, Fig. 5$)$. The heavy mineral content increases with increasing amount of mud $(r=+0.554$, $C=99 \%$ ).

The results of the textural analyses of the light mineral fraction of selected samples are given in Table 4. Mean grain size varies from 2.01 to $3.69 \phi(77-250 \mu \mathrm{m})$, with an overall mean of $2.93 \phi(131 \mu \mathrm{m})$. These values correspond to fine sand (2.0-3.0 $\phi)$ and very fine sand (3.0$4.0 \phi$ ). The correlation coefficient between textural mean (in $\phi$ units) and depth in meters is +0.630 (Fig. 6). Thus, as depth increases, there is a significant decrease in average grain size of the light mineral fraction (increase $\phi, C=99 \%$ ). Figure 7 shows the results of calculating a running mean (Davis, 1973, p. 223) of the values shown in Figure 6. This data-smoothing calculation allows vertical trends to become more apparent. A histogram of grain-size distribution for the samples examined is given in Figure 8, and a probability grain-size distribution using the same data is presented in Figure 9. The samples show some evidence of a bi- or trimodal distribution.

The degree of sorting (standard deviation) in the light mineral sand fraction decreases uphole $(r=-0.702$,

Table 5. Weight percent of Lower Cretaceous sand-size heavy minerals, Hole 603B.

\begin{tabular}{|c|c|c|c|c|c|c|c|c|c|c|c|c|c|c|c|}
\hline $\begin{array}{c}\text { Sample } \\
\text { (Core-Section, } \\
\text { interval in } \mathrm{cm} \text { ) }\end{array}$ & $\begin{array}{l}\text { Sub-bottom } \\
\text { depth } \\
\text { (m) }\end{array}$ & ZIR & TOU & RUT & AMP & APT & EPI & GRN & KYAN & LUC & SFN & STR & $\mathrm{OPQ}$ & UNK & CNT \\
\hline $45-1,67-69$ & 1224.7 & 14.6 & 1.0 & 0.5 & 0.0 & 3.4 & 42.4 & 4.4 & 0.5 & 0.0 & 1.5 & 2.4 & 14.6 & 14.6 & 205 \\
\hline $46-2,13-15$ & 1235.0 & 4.8 & 1.2 & 0.6 & 0.0 & 4.2 & 37.7 & 8.4 & 4.8 & 1.2 & 4.2 & 3.6 & 12.0 & 17.4 & 167 \\
\hline $46-2,100-102^{*}$ & 1236.1 & 4.6 & 1.5 & 0.0 & 0.5 & 0.5 & 27.4 & 6.1 & 0.5 & 1.0 & 0.0 & 4.6 & 31.0 & 22.3 & 197 \\
\hline $46-3,126-128$ & 1237.8 & 11.4 & 0.6 & 0.6 & 0.6 & 1.9 & 30.4 & 6.3 & 0.6 & 1.9 & 2.5 & 3.2 & 24,1 & 15.8 & 158 \\
\hline $46-4,5-7^{*}$ & 1240.2 & 3.2 & 0.6 & 0.0 & 1.3 & 1.9 & 22.9 & 10.2 & 2.5 & 5.1 & 1.9 & 2.5 & 22.9 & 24.8 & 157 \\
\hline $47-1,49-56^{*}$ & 1243.7 & 6.5 & 1.8 & 1.2 & 0.6 & 0.6 & 40.0 & 4.7 & 1.2 & 2.9 & 1.8 & 2.9 & 7.6 & 28.2 & 170 \\
\hline $47-1,66-68$ & 1243.9 & 2.5 & 0.5 & 0.0 & 1.5 & 4.1 & 55.3 & 4.1 & 1.5 & 0.5 & 3.0 & 1.0 & 8.1 & 17.8 & 197 \\
\hline $48-1,49-50$ & 1253.0 & 5.5 & 0.0 & 0.0 & 0.0 & 6.4 & 44.1 & 4.1 & 4.5 & 1.8 & 1.4 & 3.2 & 11.8 & 17.3 & 220 \\
\hline $48-2,100-102$ & 1255.2 & 4.4 & 0.0 & 0.0 & 0.6 & 2.2 & 37.6 & 4.4 & 2.2 & 0.6 & 0.0 & 2.2 & 26.0 & 19.9 & 181 \\
\hline $49-1,20-22^{*}$ & 1262.4 & 2.1 & 0.0 & 0.5 & 1.6 & 1.1 & 43.4 & 4.2 & 0.5 & 2.1 & 0.0 & 3.2 & 17.5 & 23.8 & 189 \\
\hline $49-1,40-42$ & 1263.0 & 4.8 & 2.0 & 0.0 & 0.0 & 4.1 & 49.0 & 4.1 & 2.7 & 0.0 & 2.0 & 4.1 & 10.9 & 16.3 & 147 \\
\hline $49-1,94-96$ & 1263.4 & 3.3 & 1.1 & 0.5 & 0.5 & 3.3 & 28.3 & 4.3 & 2.2 & 1.6 & 1.1 & 3.8 & 35.3 & 14.7 & 184 \\
\hline $50-1,113-114$ & 1273.0 & 23.3 & 2.1 & 1.1 & 0.0 & 14.3 & 5.3 & 18.0 & 6.3 & 0.0 & 1.1 & 3.2 & 7.4 & 18.0 & 189 \\
\hline $52-5,107-109$ & 1298.0 & 6.4 & 3.7 & 0.5 & 0.5 & 8.3 & 25.2 & 10.1 & 2.3 & 3.2 & 0.9 & 6.0 & 22.0 & 11.0 & 218 \\
\hline $54-4,55-56$ & 1315.5 & 3.3 & 0.7 & 0.0 & 2.0 & 13.9 & 29.1 & 9.3 & 1.3 & 0.7 & 4.0 & 4.6 & 15.2 & 15.9 & 151 \\
\hline $55-3,95-96^{*}$ & 1324.0 & 1.4 & 0.0 & 0.0 & 1.4 & 0.0 & 7.2 & 13.0 & 2.9 & 0.0 & 2.9 & 2.9 & 8.7 & 59.4 & 69 \\
\hline $56-2,133-135$ & 1332.4 & 12.6 & 0.0 & 0.8 & 0.0 & 10.9 & 8.4 & 8.4 & 5.9 & 2.5 & 0.0 & 5.0 & 24.4 & 21.0 & 119 \\
\hline $57-5,37-38$ & 1346.0 & 9.3 & 0.5 & 0.0 & 0.0 & 4.7 & 20.0 & 9.8 & 4.7 & 0.9 & 0.0 & 4.7 & 26.0 & 19.5 & 215 \\
\hline $57-6,26-27^{*}$ & 1347.0 & 7.4 & 0.0 & 0.0 & 0.0 & 10.5 & 13.6 & 4.9 & 16.7 & 1.2 & 0.0 & 4.9 & 17.3 & 23.5 & 162 \\
\hline $58-1,50-51$ & 1349.3 & 9.8 & 0.9 & 0.5 & 0.0 & 11.6 & 13.0 & 11.2 & 4.7 & 2.3 & 0.0 & 0.6 & 26.5 & 13.5 & 215 \\
\hline $60-1,35-37$ & 1368.4 & 16.9 & 3.4 & 1.1 & 0.6 & 19.1 & 14.6 & 3.4 & 6.7 & 1.7 & 0.6 & 10.7 & 10.1 & 11.2 & 178 \\
\hline $61-1,51-52$ & 1378.0 & 14.5 & 5.6 & 0.0 & 0.0 & 19.4 & 12.1 & 7.3 & 3.2 & 0.0 & 0.0 & 8.1 & 16.9 & 12.9 & 124 \\
\hline $62-2,113-114$ & 1389.4 & 14.8 & 0.9 & 2.6 & 0.0 & 13.9 & 9.6 & 2.6 & 5.2 & 3.5 & 0.0 & 7.8 & 22.6 & 16.5 & 115 \\
\hline $63-7,16-17$ & 1405.3 & 9.0 & 3.6 & 0.9 & 0.4 & 17.9 & 8.5 & 15.2 & 2.2 & 2.7 & 0.9 & 4.9 & 27.4 & 6.3 & 223 \\
\hline $65-2,86-87$ & 1417.0 & 18.3 & 3.4 & 0.6 & 0.6 & 13.7 & 4.6 & 10.9 & 2.9 & 1.1 & 1.1 & 7.4 & 25.7 & 9.7 & 175 \\
\hline $66-5,23-24$ & 1430.0 & 13.6 & 1.7 & 1.1 & 0.0 & 18.8 & 11.4 & 15.9 & 1.1 & 1.7 & 2.3 & 1.7 & 17.0 & 13.6 & 176 \\
\hline $70-2,28-29$ & 1461.3 & 16.1 & 6.3 & 0.7 & 0.0 & 13.3 & 5.6 & 19.6 & 6.3 & 0.0 & 1.4 & 7.7 & 8.4 & 14.7 & 143 \\
\hline $71-1,117-118$ & 1470.0 & 16.0 & 1.5 & 1.5 & 0.0 & 15.5 & 2.9 & 12.1 & 4.4 & 2.4 & 1.5 & 7.8 & 13.8 & 10.7 & 206 \\
\hline $73-2,93-94$ & 1495.1 & 24.7 & 3.3 & 1.2 & 0.4 & 14.8 & 3.3 & 17.3 & 2.5 & 0.0 & 1.2 & 4.9 & 12.3 & 14.0 & 243 \\
\hline Average & & 11.3 & 1.9 & 0.6 & 0.3 & 10.4 & 21.7 & 9.2 & 3.4 & 1.3 & 1.3 & 5.0 & 18.6 & 14.9 & 180 \\
\hline Standard deviation & & 6.2 & 1.7 & 0.6 & 0.5 & 5.9 & 15.9 & 5.1 & 1.9 & 1.1 & 1.2 & 2.4 & 7.6 & 3.5 & 35 \\
\hline Minimum & 1224.7 & 2.5 & 0 & 0 & 0 & 1.9 & 2.9 & 2.6 & 0.5 & 0 & 0 & 1 & 7.4 & 6.3 & 115 \\
\hline Maximum & 1495.1 & 24.7 & 6.2 & 2.6 & 2 & 19.4 & 55.3 & 19.6 & 6.7 & 3.4 & 4.1 & 10.7 & 35.3 & 21 & 243 \\
\hline Count & 23 & 23 & 23 & 23 & 23 & 23 & 23 & 23 & 23 & 23 & 23 & 23 & 23 & 23 & 23 \\
\hline
\end{tabular}

Note: $\mathrm{ZIR}=$ zircon, $\mathrm{TOU}=$ tourmaline, $\mathrm{RUT}=$ rutile, $\mathrm{AMP}=$ amphibole, $\mathrm{APT}=$ apatite, $\mathrm{EPI}=$ epidote, $\mathrm{GRN}=$ garnet, $\mathrm{KYAN}=\mathrm{kyanite}, \mathrm{LUC}$ $=$ leucoxene, $\mathrm{SFN}=$ sphene, $\mathrm{STR}=$ staurolite, $\mathrm{OPQ}=$ opaque, $\mathrm{UNK}=$ unknown, $\mathrm{CNT}=$ grain count. ${ }^{*}$ indicates samples excluded from statistical analysis. 


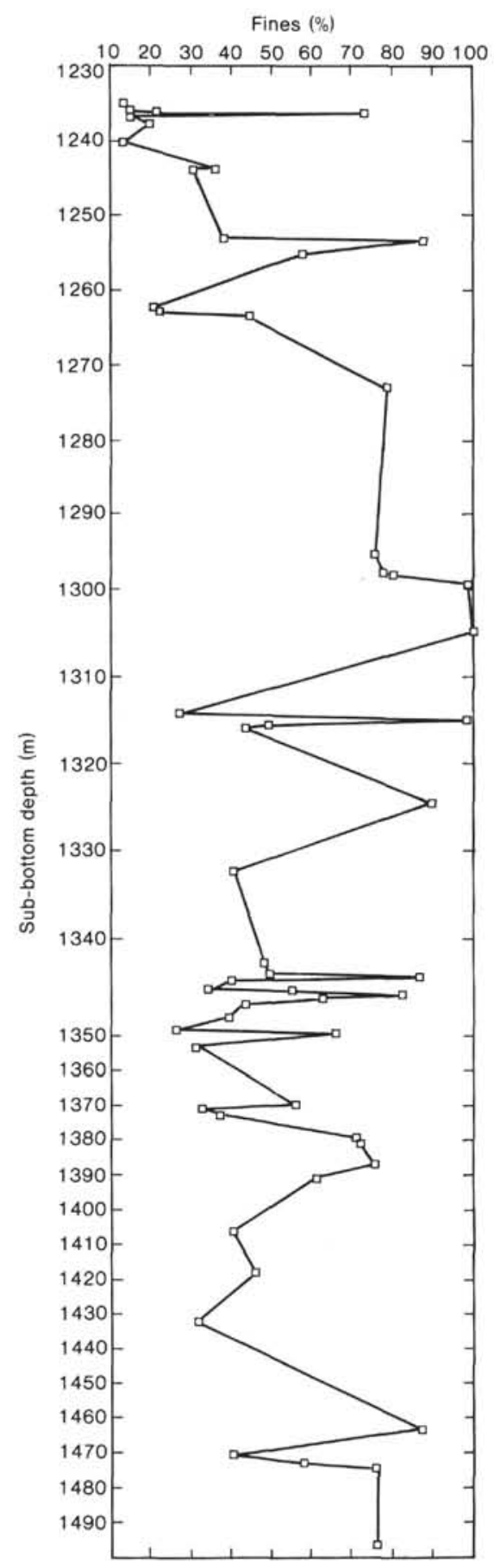

Figure 4. Vertical distribution of percent fines (mud). Note change in depth scale at $1350 \mathrm{~m}$.

$C=99 \%$ ), as shown in Table 4 and Figure 10 . The running mean of sorting versus depth shown in Figure 11 illustrates this trend more clearly. Most samples are moderately well sorted, very fine sand. Mean grain size of the light mineral fraction is negatively correlated with sorting ( $r=-0.666, C=99 \%$, Fig. 12), indicating that as the sediment becomes coarser, it becomes more poorly sorted. Sandier units thus have coarser, more poorly sorted sand.

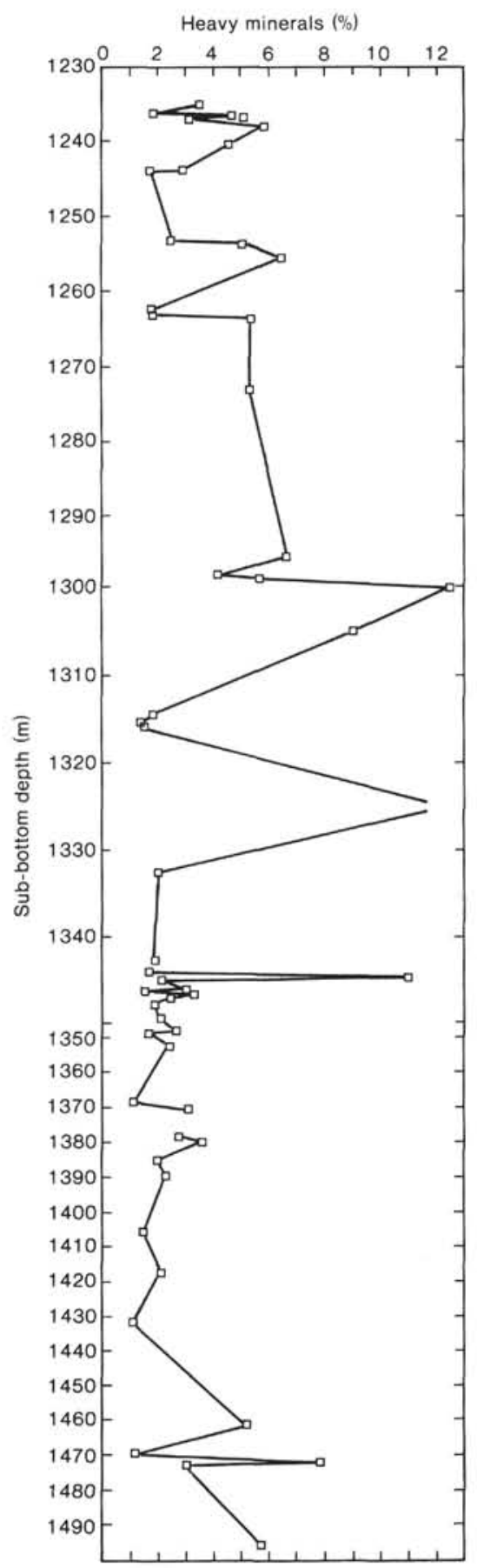

Figure 5. Vertical distribution of percent heavy minerals. Note change in depth scale at $1350 \mathrm{~m}$.

Most samples are negatively skewed and show no regular variation in skewness with depth $(r=-0.28$, Fig. 13). Skewness is negatively correlated with percent fines $(r=-0.676, C=99 \%)$. Therefore, as skewness values for the light mineral sand fraction decrease (become more skewed toward the fine fraction), the amount of silt and clay increases. All of the light mineral sand fractions were very to extremely leptokurtic (Table 4), which indicates that sand in the central sand fractions is better 


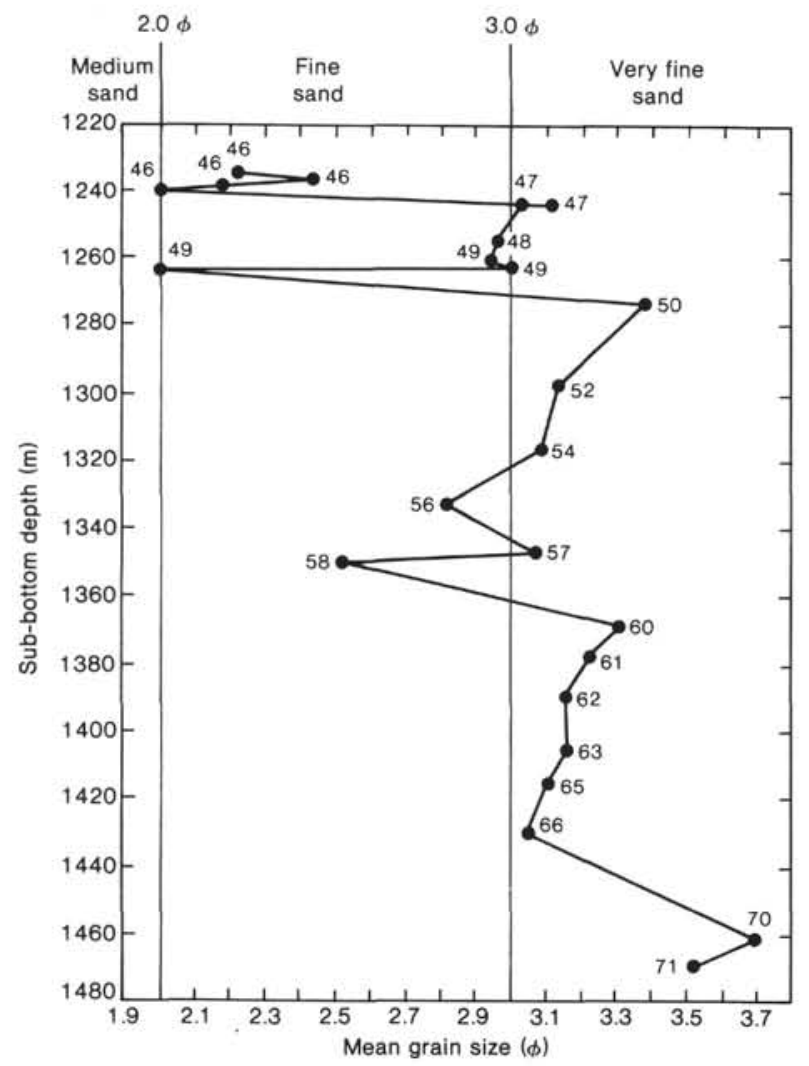

Figure 6. Vertical distribution of mean grain size of the light mineral fraction. Numbers indicate cores.

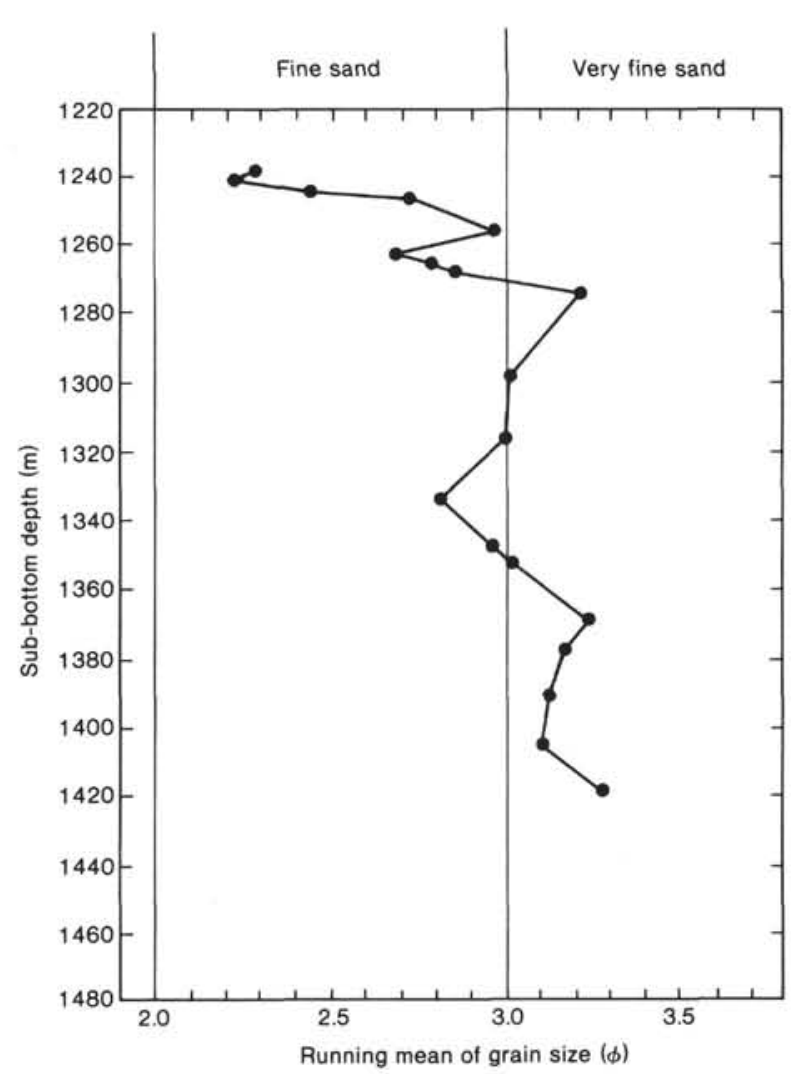

Figure 7. Running mean of light mineral fraction downhole.

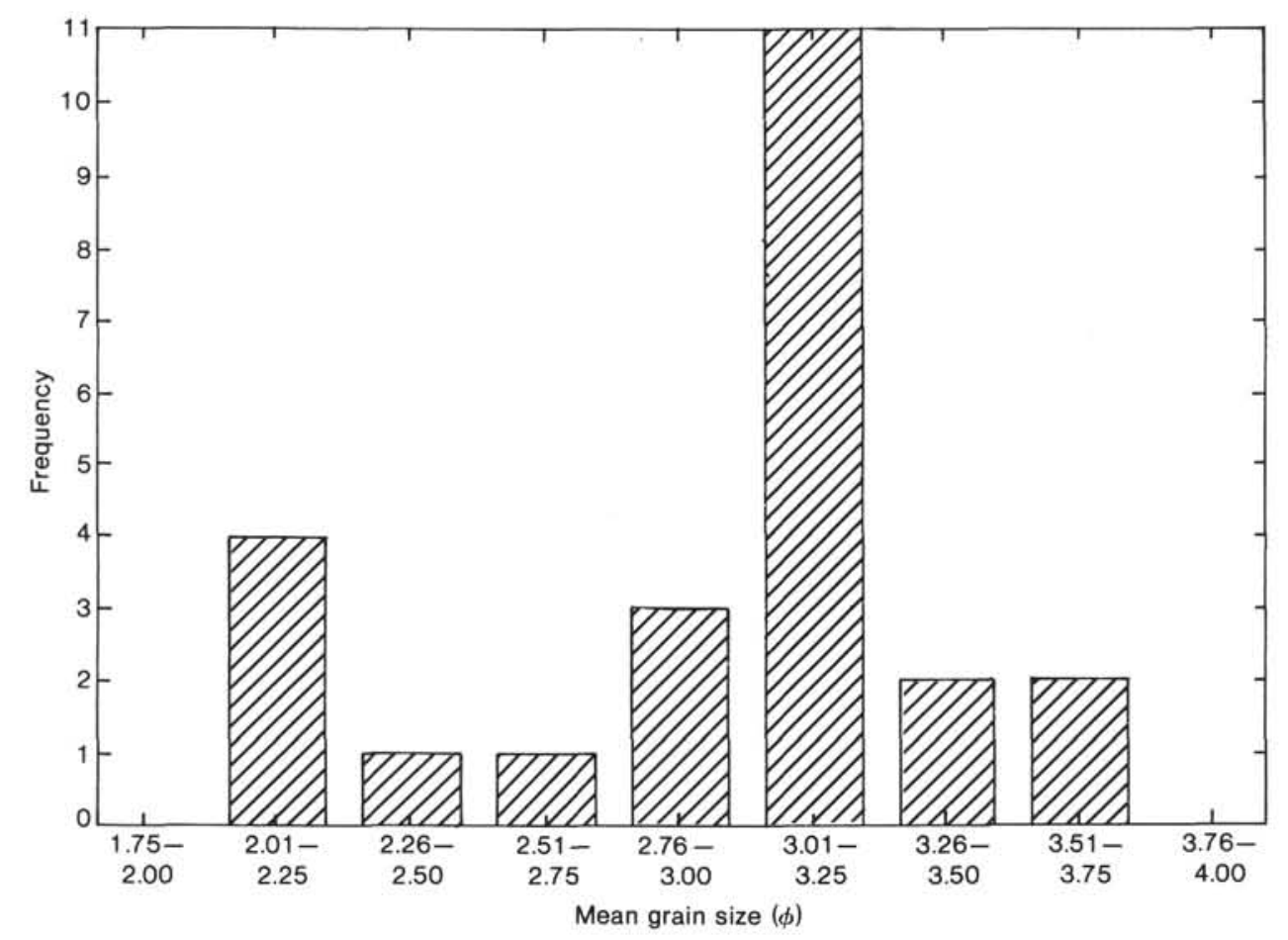

Figure 8. Histogram of mean grain size of light mineral sand fraction. 


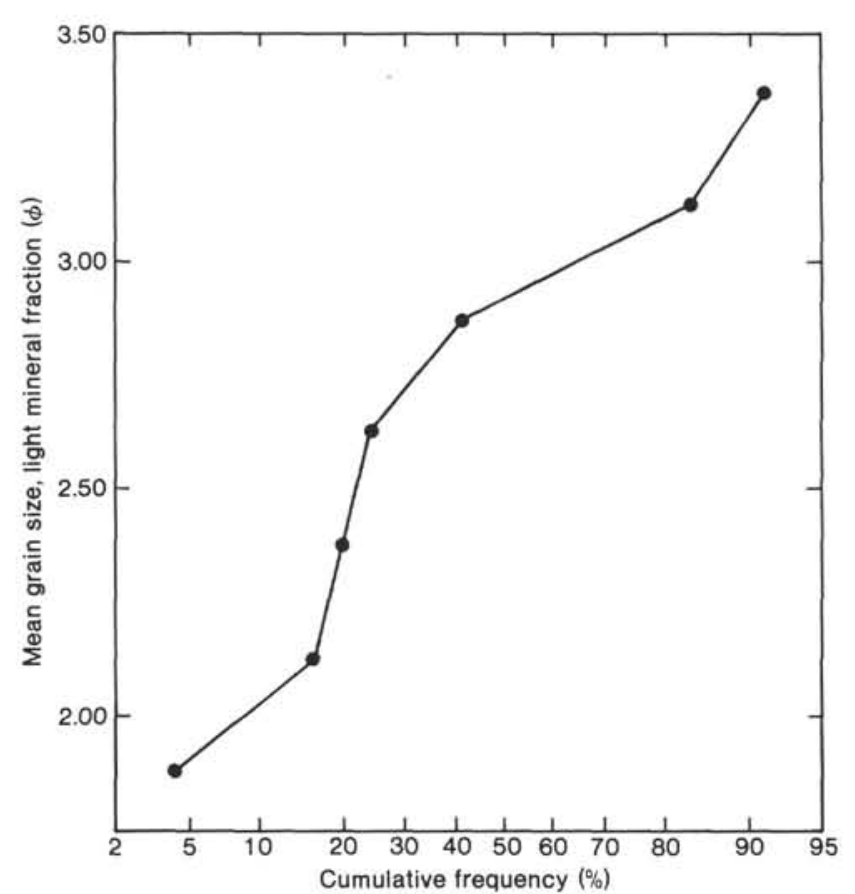

Figure 9. Probability plot of means of light mineral sand fraction.

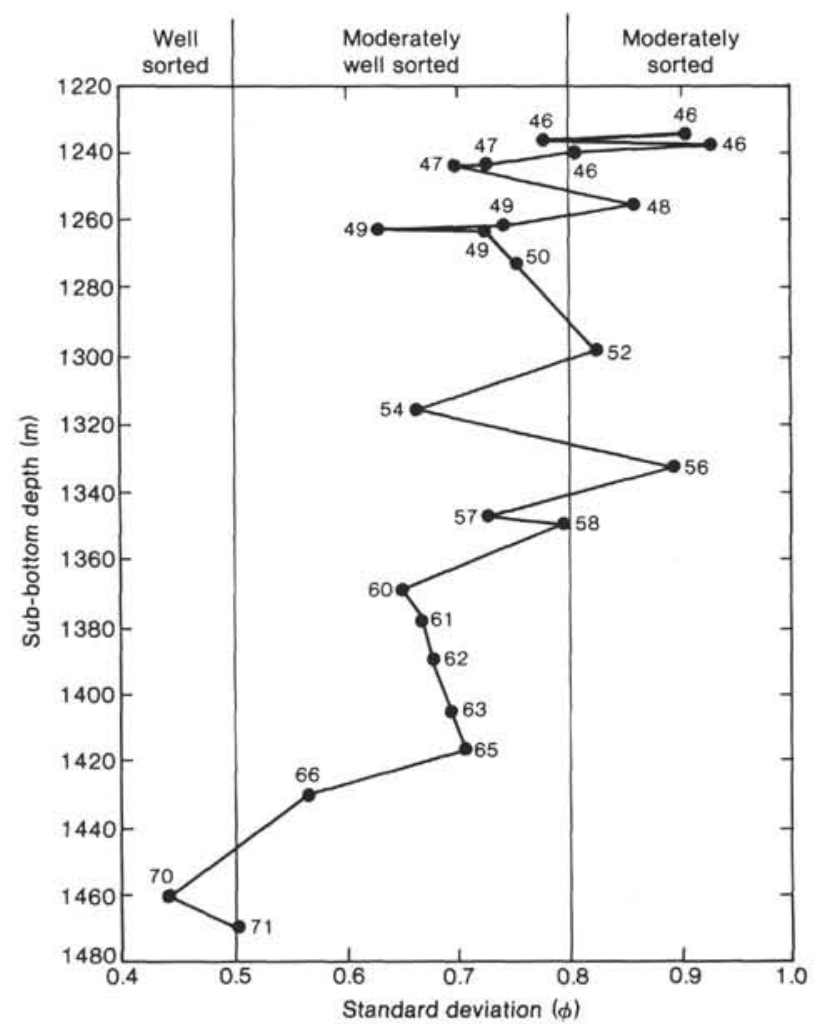

Figure 10. Vertical distribution of sorting of the light mineral fraction. Numbers indicate cores sampled in Hole 603B.

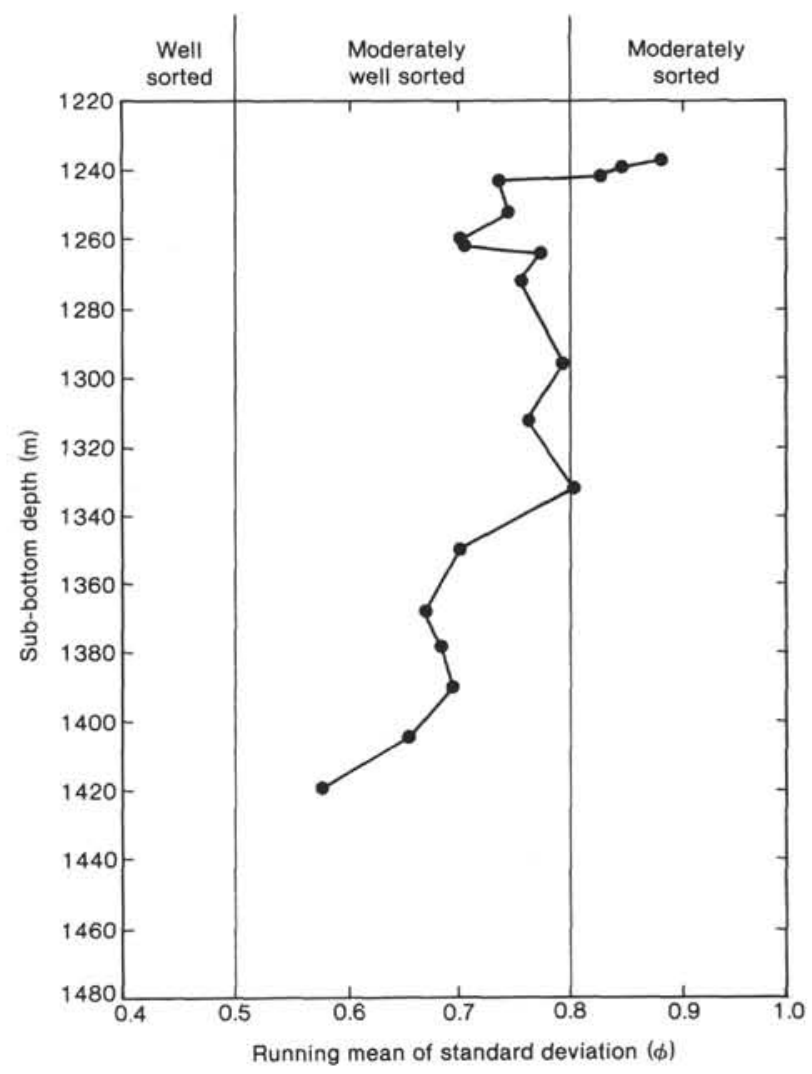

Figure 11. Running mean of sorting of the light mineral fraction downhole.

sorted than that in upper or lower fractions. Kurtosis shows no relationship with depth $(r=-0.077)$.

\section{Heavy Mineral Distribution}

The results of the heavy mineral grain counts were complicated by the presence of abundant authigenic siderite and pyrite. Six of the 29 samples were not included in statistical analyses because of higher proportions of unidentified or authigenic minerals; these are indicated by asterisks in Table 5 . Averages and correlation coefficients reported here and in Tables 5 and 6 were calculated using 23 samples.

\section{Ultrastables}

The heavy minerals most resistant to physical and chemical weathering are ultrastable zircon, tourmaline, and rutile (Pettijohn, 1941). The sums of the proportions of these three minerals (ZTR) in the samples examined are shown against sub-bottom depths in Figure 14A. Zircon is the most abundant mineral in this group, and its behavior dominates that of the ZTR sum. ZTR values range from 3\% in Section 603B-47-1 to $29 \%$ in Section 603B-73-2, and average $14 \%$ of the total heavy mineral assemblage. ZTR levels decrease uphole $(r=+0.675$, $C=99 \%$ ), but are higher in Aptian samples (12\%) than in Barremian samples (9\%, Table 6). ZTR levels significantly increase with increasing amounts of mud $(r=+0.580, C=99 \%)$ and with decreasing average grain size of the light mineral fraction $(r=+0.583$, 


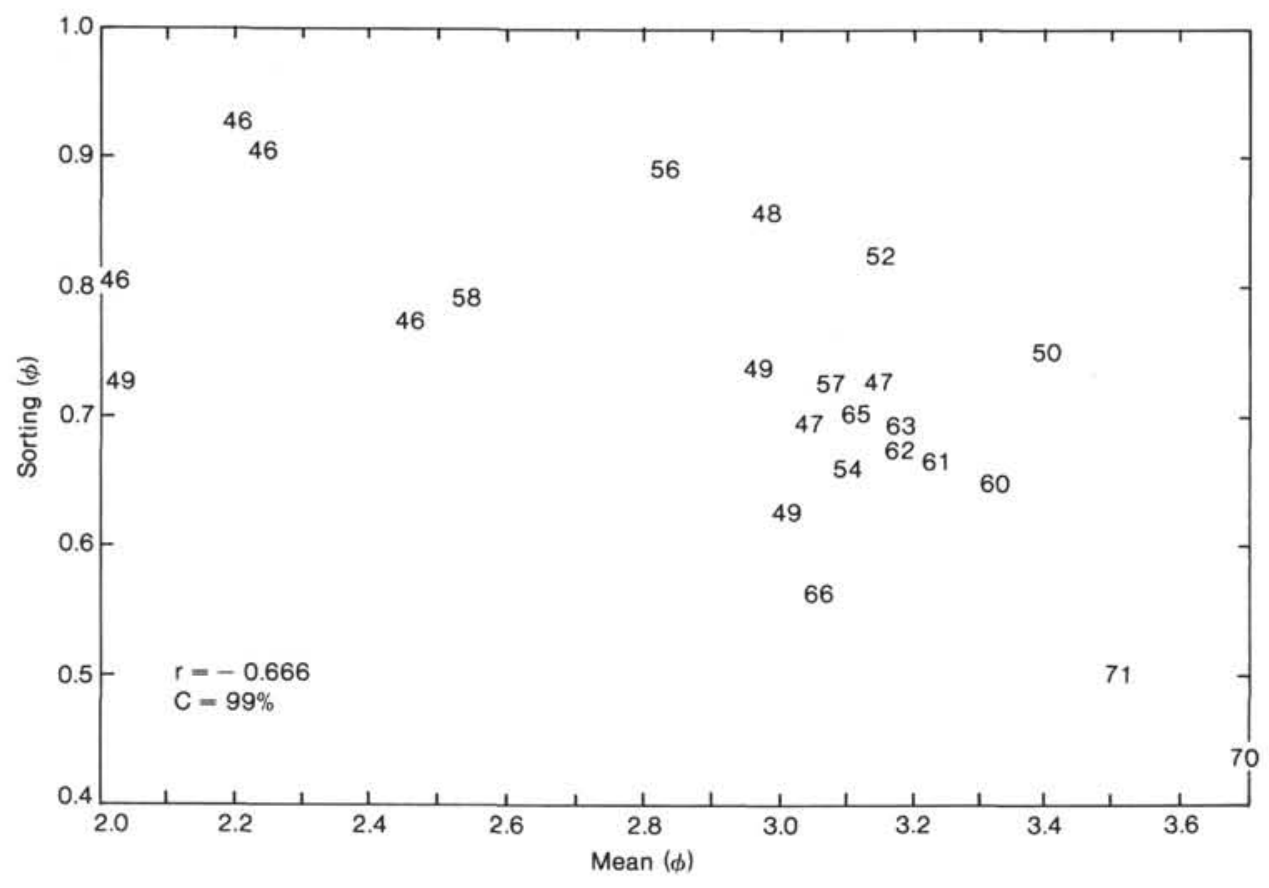

Figure 12. Mean versus sorting of the light mineral fraction. Numbers indicate Hole 603B cores sampled for this study (cf. Figs. 10 and 13).

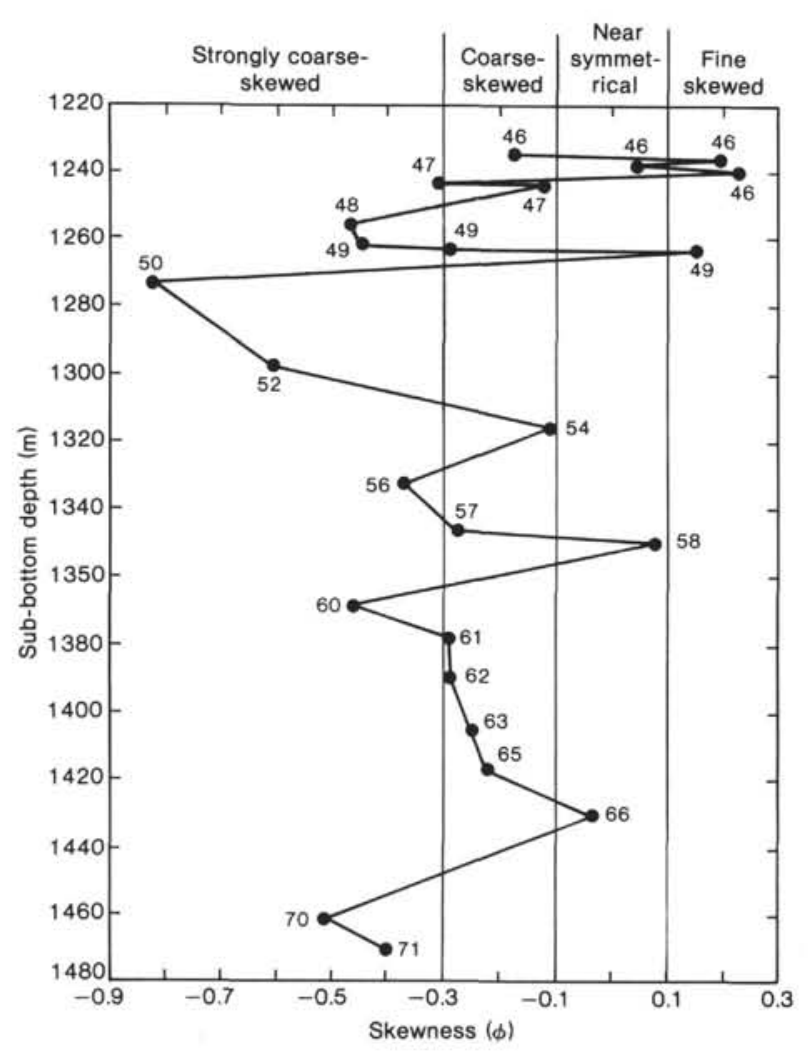

Figure 13. Vertical distribution of skewness of the light mineral sand fraction. grain size in $\phi$ units, $C=99 \%$ ). Zircon and tourmaline significantly increase with increasing percent fines $(r=$ +0.511 and $+0.613, C=95 \%$ and $99 \%$, respectively).

Zircon is the most abundant ultrastable mineral identified, averaging $11 \%$ of the total heavy mineral assemblage. Throughout the section zircon appears with inclusions, in euhedral (prismatic), subhedral, and anhedral crystal forms, and with etched and pitted surface features (Plate 1, Figs. 7-9). Zircon levels significantly decrease uphole $(r=+0.612, C=99 \%$, Fig. 14B). However, when the samples are grouped by age (Table 6), zircon levels increase in Aptian sediment. Zircon levels are positively correlated with apatite $(r=+0.591, C=$ $99 \%)$, rutile $(r=+0.571, C=99 \%)$, and garnet $(r=$ $+0.535, C 99 \%$ ), and negatively correlated with epidote levels $(r=-0.749, C=99 \%)$. These correlations reflect the fact that zircon, apatite, and garnet levels decrease uphole, whereas epidote levels increase.

Throughout the hole tourmaline appears with inclusions, in euhedral (prismatic) to anhedral crystal forms, and with etched and pitted surface features (Plate 1, Fig. 11, 12). The tourmaline content significantly decreases uphole $(r=+0.551, C=99 \%$, Fig. 14C) and clearly decreases in younger-age sediment (Table 6). Tourmaline levels average $2 \%$ of the total heavy mineral assemblage. Tourmaline levels are positively correlated with apatite $(r+0.572, C=99 \%)$ and staurolite levels $(r=$ $+0.574, C=99 \%)$. These relationships reflect the fact that each of these minerals decreases upcore.

Rutile appears in euhedral (prismatic) crystal forms throughout the hole. The average content is $0.5 \%$ of the heavy mineral assemblage and its concentration decreases uphole ( $r=+0.503, C=95 \%$, Fig. 14D).

The degree of etching and pitting on zircon and tourmaline grains varies throughout the section but is great- 
M. A. HOLMES, J. R. BREZA, S. W. WISE, JR.
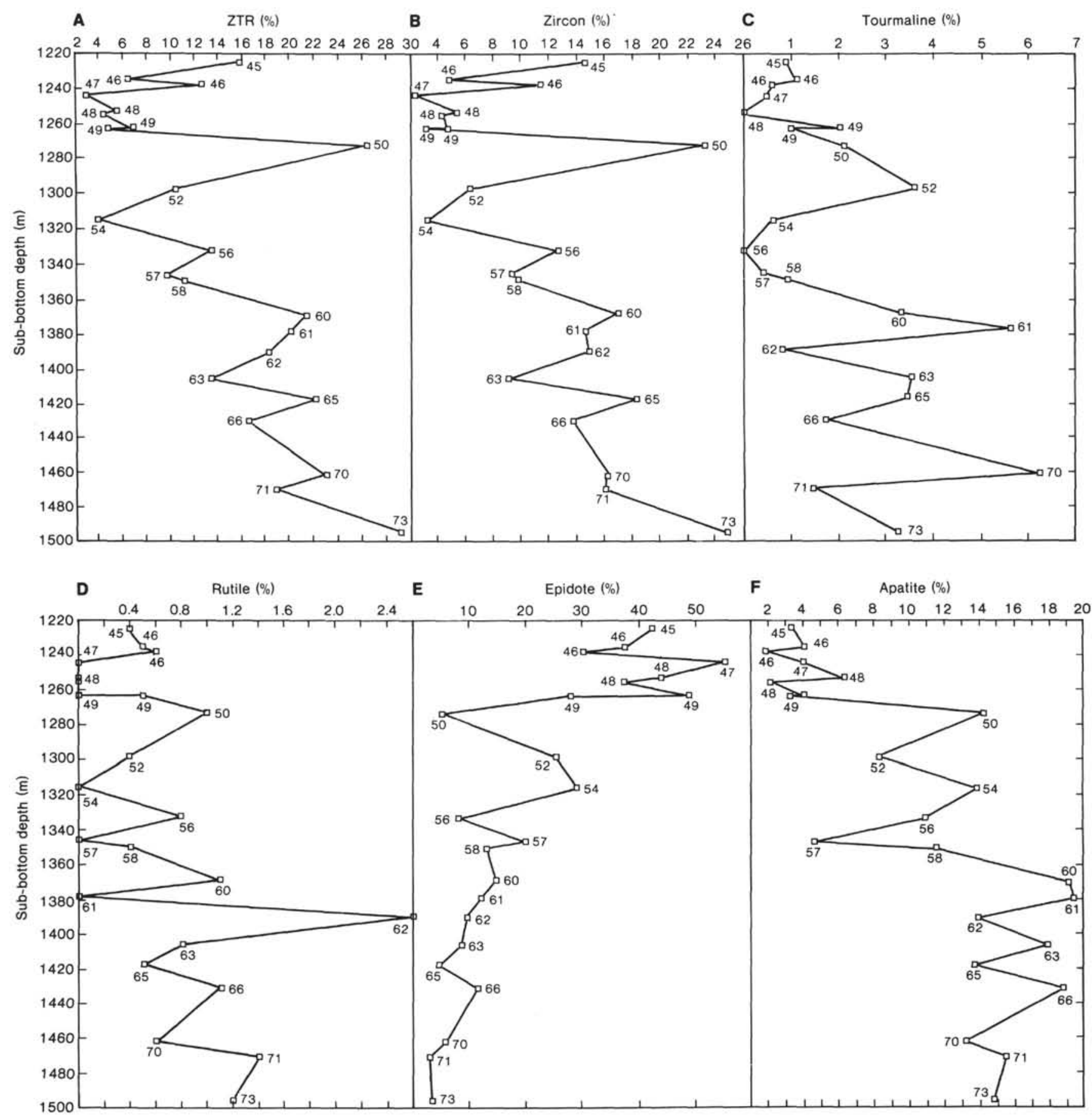

Figure 14. A. Vertical distribution of zircon-tourmaline-rutile (ZTR). Vertical distributions of (B) zircon, (C) tourmaline, (D) rutile, (E) epidote, (F) apatite, $(\mathrm{G})$ garnet, $(\mathrm{H})$ staurolite and $(\mathrm{I})$ kyanite.

est in samples from Cores 603B-49 through -46. Etching and pitting of tourmaline and zircon grains ranges from 0 to $100 \%$. Rutile, on the other hand, has only a small amount of etching and pitting (less than $10 \%$ of the grains in any given sample).

\section{METASTABLES}

The metastable group in Site 603 sediment consists of apatite, epidote, garnet, kyanite, leucoxene, sphene, and staurolite (Table 5). One sample (from Section 603B-58-
1) contains sillimanite. The metastable group comprises $53 \%$ of the total heavy mineral assemblage in this analysis. The most abundant metastable minerals are epidote $(22 \%)$, apatite $(10 \%)$, garnet $(9 \%)$, staurolite $(5 \%)$, and kyanite $(3 \%$ ) (Table 5 ).

Epidote averages $22 \%$ of the total heavy mineral assemblage and is the most abundant mineral. Epidote is the only mineral to increase in abundance uphole $(r=$ $-0.824, C=99 \%$, Fig. 14F). It is most abundant in Cores $603 \mathrm{~B}-49$ through -45 , where it constitutes an average 


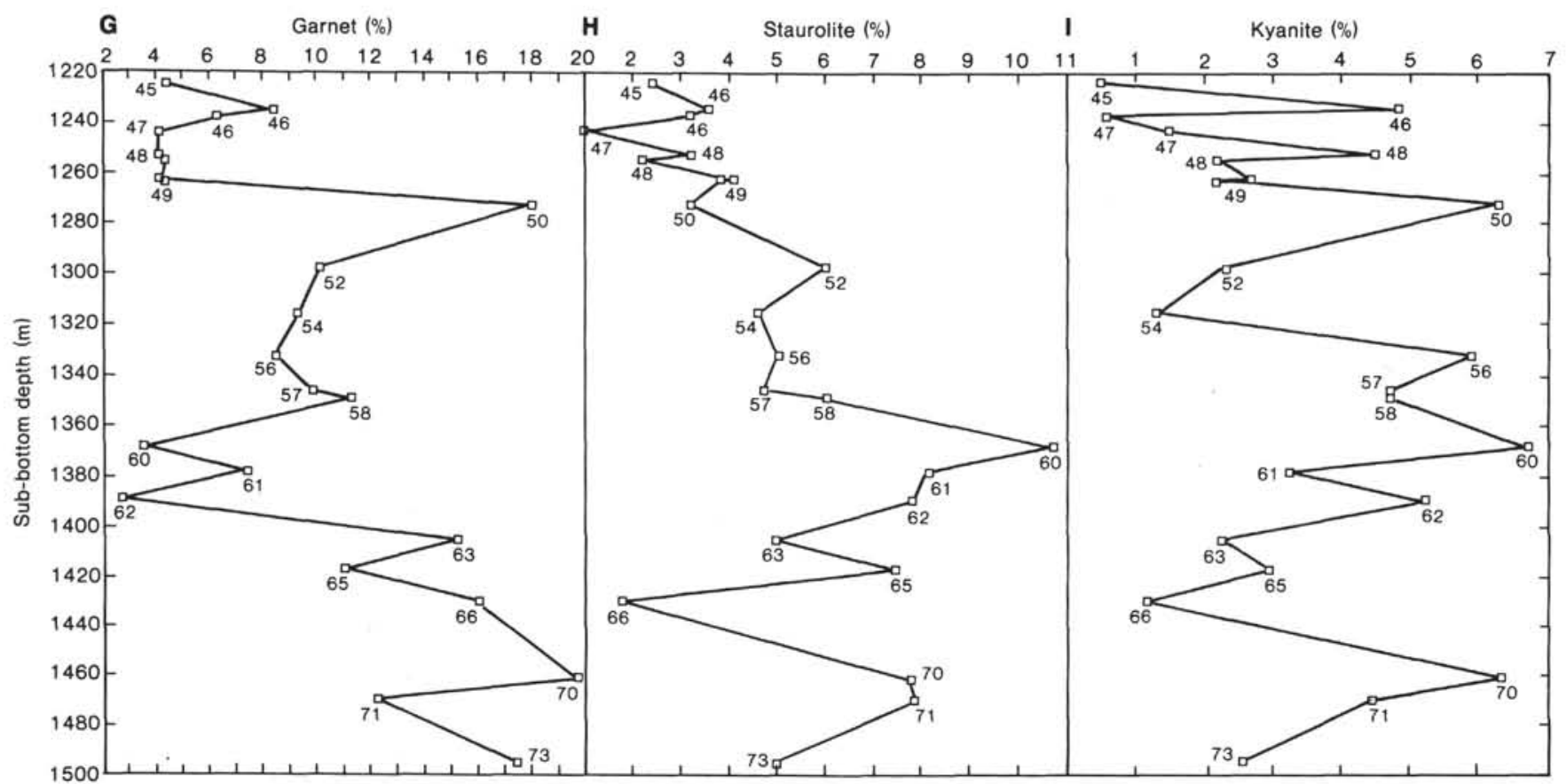

Figure 14 (continued).

Table 6. Proportions of Hole 603B Lower Cretaceous heavy minerals according to age (standard deviations-STD-in parentheses).

\begin{tabular}{|c|c|c|c|c|c|c|c|c|c|c|c|c|c|c|c|}
\hline Age & ZIR & TOU & RUT & ZTR & AMP & APT & EPI & GRN & KYAN & wc & SFN & STR & OPQ & UNK & CNT \\
\hline $\begin{array}{l}\text { Avg. Aptian } \\
\text { (STD APTIAN) }\end{array}$ & $\begin{array}{l}10.2 \\
(4.08)\end{array}$ & $\begin{array}{c}0.86 \\
(0.20)\end{array}$ & $\begin{array}{l}0.5 \\
(0.08)\end{array}$ & $\begin{array}{l}11.6 \\
(3.93)\end{array}$ & $\begin{array}{l}0.2 \\
(0.28)\end{array}$ & $\begin{array}{l}3.16 \\
(0.95)\end{array}$ & $\begin{array}{l}36.8 \\
(4.93)\end{array}$ & $\begin{array}{r}6.36 \\
(1.63)\end{array}$ & $\begin{array}{l}1.96 \\
(2.00)\end{array}$ & $\begin{array}{l}0.96 \\
(0.74)\end{array}$ & $\begin{array}{c}2.66 \\
(1.10)\end{array}$ & $\begin{array}{r}3.06 \\
(0.49)\end{array}$ & $\begin{array}{l}16.9 \\
(5.20)\end{array}$ & $\begin{array}{l}15.9 \\
(1.14)\end{array}$ & $\begin{array}{l}176 \\
(20)\end{array}$ \\
\hline $\begin{array}{l}\text { Avg. Barremian } \\
\text { (STD BARR.) }\end{array}$ & $\begin{array}{l}7.74 \\
(5.76)\end{array}$ & $\begin{array}{l}1.00 \\
(1.07)\end{array}$ & $\begin{array}{l}0.28 \\
(0.34)\end{array}$ & $\begin{array}{l}9.03 \\
(6.37)\end{array}$ & $\begin{array}{l}0.44 \\
(0.65)\end{array}$ & $\begin{array}{r}7.61 \\
(4.19)\end{array}$ & $\begin{array}{l}28.6 \\
(15.7)\end{array}$ & $\begin{array}{c}7.98 \\
(4.17)\end{array}$ & $\begin{array}{l}3.48 \\
(1.69)\end{array}$ & $\begin{array}{l}1.26 \\
(1.03)\end{array}$ & $\begin{array}{l}1.19 \\
(1.24)\end{array}$ & $\begin{array}{l}3.98 \\
(1.45)\end{array}$ & $\begin{array}{l}19.4 \\
(8.74)\end{array}$ & $\begin{array}{l}16.8 \\
(2.81)\end{array}$ & $\begin{array}{l}185 \\
\text { (31) }\end{array}$ \\
\hline $\begin{array}{l}\text { Avg. Hauterivian } \\
\text { (STD HAUT.) }\end{array}$ & $\begin{array}{l}14.9 \\
(2.61)\end{array}$ & $\begin{array}{l}3.23 \\
(1.80)\end{array}$ & $\begin{array}{l}1.01 \\
(0.72)\end{array}$ & $\begin{array}{l}19.1 \\
(2.99)\end{array}$ & $\begin{array}{l}0.17 \\
(0.22)\end{array}$ & 16.4 & $\begin{array}{l}8.66 \\
(3.78)\end{array}$ & $\begin{array}{l}10.8 \\
(5.68)\end{array}$ & $\begin{array}{l}4.00 \\
(1.86)\end{array}$ & 1.6 & $\begin{array}{l}0.91 \\
(0.70)\end{array}$ & $\begin{array}{l}7.01 \\
(2.48)\end{array}$ & $\begin{array}{l}18.9 \\
(6.62)\end{array}$ & $\begin{array}{l}11.9 \\
(2.97)\end{array}$ & $\begin{array}{l}167 \\
\text { (35) }\end{array}$ \\
\hline "Avg." Valaginian (Sample 603B-73-2, 93-94 cm) & 24.7 & 3.2 & 1.2 & 1.2 & 0.4 & 14.8 & $\begin{array}{l}(3.78) \\
3.3\end{array}$ & 17.3 & 2.5 & 0.0 & 1.2 & 4.9 & 12.3 & 14.0 & 243 \\
\hline
\end{tabular}

Note: See Table 5 for identification of abbreviated headings.

$41 \%$ of the total heavy mineral suite. Epidote tends to be angular to subrounded throughout the section (Plate 1, Figs. 1 and 6), with etching occurring on at least $75 \%$ of the grains in samples from Sections 603B-57-5 and 603B-54-4, and from Sample 603B-49-1, 40-42 cm through Core 603B-46. Some of these epidote grains are coated with iron oxide. Epidote abundance is positively correlated only with sphene $(r=+0.463, C=95 \%)$. Epidote has strong antithetic relationships with apatite $(r=-0.777)$, zircon $(r=-0.749)$, and garnet $(r=$ -0.663 ), minerals that have positive correlations with depth.

Apatite levels average $10 \%$ and are second highest among the metastable minerals. Apatite concentration decreases significantly uphole $(r=+0.778, C=99 \%$, Fig. 14F). This mineral occurs throughout the core as subrounded, unaltered, prismatic grains with a small degree of etching (Plate 1, Fig. 10). Inclusions in apatite are present but not common. Apatite is one of the least stable of heavy minerals (Pettijohn, 1941) and may be destroyed in sample preparation by treatment with strong acids. The etched appearance of some apatite grains may indicate that some intrastratal solution has occurred at this site. However, the presence of as much as $19 \%$ apatite in some samples (Cores 603B-60 and -61) indicates that dissolution of heavy minerals in this sediment has been minimal. Apatite levels are most strongly correlated with those of staurolite $(r=+0.60)$, zircon $(r=$ $+0.59)$, and tourmaline $(r=+0.57)$. These correlation coefficients are significant at the $99 \%$ confidence level. At the $95 \%$ confidence level, apatite is significantly correlated with garnet $(r=+0.51)$ and rutile $(r=+0.47)$.

The amount of garnet averages $9 \%$ throughout the section and decreases uphole $(r=+0.617, C=99 \%$, Fig. 14G). Garnet grains are etched, rounded to angular, and some exhibit conchoidal fractures (Plate 1, Fig. 1, 2 , and 5). Through chemical etching, the grains have developed pitted, V-shaped, and embayed surface features. Etching occurs on $77 \%$ of the garnet grains throughout the section. In the interval from Cores 603B-62 to -60 , garnet levels decrease to an average $4 \%$. Levels increase again from Cores 603B-58 to -50 and then decline from Cores $603 \mathrm{~B}-49$ through -45 . This pattern is unique to garnet and may account for the fact that garnet has the lowest correlation with zircon, apatite, epidote, and other minerals. The only positive correlation of garnet that is significant at the $99 \%$ confidence level is its correlation with zircon $(r=+0.535)$.

The abundance of staurolite averages $5 \%$ throughout the sequence. Staurolite levels show a weak tendency 
to increase uphole from Core 603B-73 to Core 603B-60 $(r=-0.40)$, where a maximum amount of $11 \%$ is reached (Fig. 14H). From Cores 603B-58 through -45 staurolite levels significantly decrease $(r=+0.78, C=$ $99 \%$ ). Etching and pitting of staurolite grains is especially evident both at the top of the sequence in Samples 603B-49-1, 94-96 and 603B-49-1, 20-22 cm and Cores $603 \mathrm{~B}-48$ and -47 , and at the bottom of the sequence in Sections 603B-71-1, 603B-65-2, and 603B-63-7. Grains from the middle of the section do not show as much degradation (compare Plate 1, Figs. 3 and 4). Etching affected $90 \%$ of the identified staurolite grains. Staurolite abundance is positively correlated $(C=99 \%)$ with that of apatite $(r=+0.601)$, tourmaline $(r=+0.574)$, and kyanite $(r=+0.563)$.

Kyanite levels average $3 \%$ of the heavy mineral suite and show no relationship with depth $(r=+0.255$, Fig. 14I). However, they do show a decrease in abundance with decreasing age (Table 6). At the $99 \%$ confidence level, kyanite is positively correlated with staurolite ( $r=$ +0.563 ).

Leucoxene, sphene, and amphibole each represent less than $2 \%$ of the heavy mineral suite, and none show any correlation with depth (Fig. 15). Sphene appears as subrounded grains throughout the hole and, as mentioned previously, is the only mineral that shows a positive correlation with epidote.

\section{OPAQUES}

Opaque minerals in this study represent the second largest portion of the heavy mineral assemblage, averaging $19 \%$. The opaque assemblage consists of ilmenite and magnetite. These grains are generally subangular to rounded throughout the hole with a small degree of etching on the surface of the grains. Opaques show no variation with depth $(r=+0.068)$ and are positively correlated with leucoxene $(r=+0.552, C=99 \%)$.

\section{UNKNOWNS}

Unknown heavy minerals constitute 6 to $21 \%$ of the total heavy mineral assemblage. These are grains that lack distinctive optical properties, are masked by a coating of iron oxide, or are in unusual optical orientations. The average content of unknown minerals is $15 \%$.

\section{DISCUSSION}

The results of the textural analysis are comparable with those of both modern and ancient deep sea fan sediments. Nelson and Nilsen (1974) reported that the average grain size in sand units from complete Bouma $\left(\mathrm{T}_{\mathrm{a}-\mathrm{e}}\right)$ sequences ranges from 3.29 to $5.24 \phi$ for high-matrix Astoria Fan sand (Holocene), and from 1.53 to $1.89 \phi$ for low-matrix Butano Fan sand (Eocene). For sand units in truncated Bouma $T_{a b}$ sequences, mean grain size tends to be coarser, 2.48 to $3.15 \phi$ for sand from Astoria and Butano fan sediment. Values for truncated Bouma $T_{c d}$ sand units vary from 3.25 to $5.12 \phi$. Hemipelagic mud has mean grain sizes from 8 to $9.56 \phi$. The sand in these units is poorly sorted and positively skewed. The results of this study coincide with those of Nelson and Nilsen's (1974) results for sand from high-matrix, complete Bouma

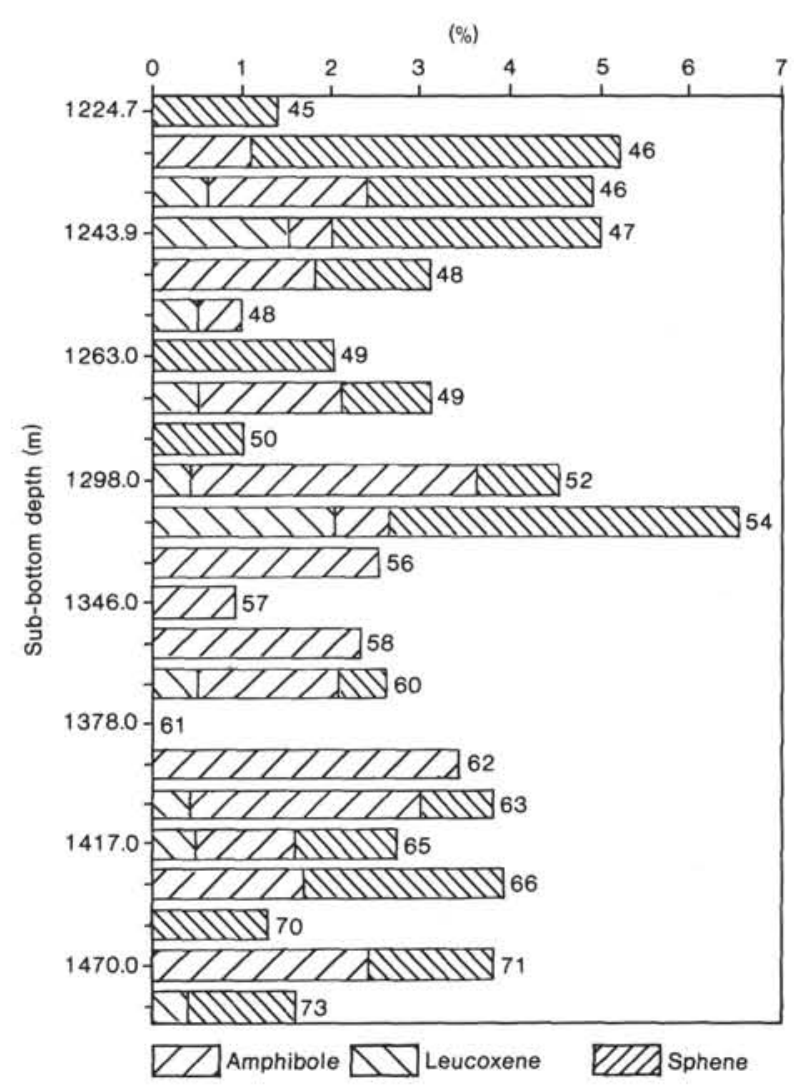

Figure 15. Vertical distribution of leucoxene, sphene, and amphibole.

sequences to truncated Bouma $T_{a b}$ sequences. Siemers (1981) reported that sandstone from the Woodbine-Eagle Ford turbidites (Upper Cretaceous, Texas) has a mean grain size varying from 2.36 to $3.79 \phi$ and is moderately to well sorted. Overall mean grain size is $3.07 \phi$. Siemers (1981) postulated that the good sorting of these sandstones resulted from sorting processes on the shelf prior to turbiditic redeposition. The sediment from Site 603 may be analogous in that it may have undergone some sorting on the shelf prior to becoming entrained in turbidity currents, particularly in the lower part of the sequence.

The texture of sediment in the turbidite sequence of Site 603 varies from well to moderately sorted, very fine sand at the base, through moderately well sorted, very fine to fine sand in the middle, to moderately sorted, fine sand at the top. These results indicate that the nature of the material available for fan or apron development changed in character as deposition proceeded, becoming coarser and more poorly sorted, or that flow regimes increased. This may indicate that (1) the fan or apron depocenter was migrating toward Site 603, (2) sorting on the shelf prior to redeposition was decreasing, (3) a different source of material was being supplied to the fan or apron, or (4) a combination of these. This new source may have had a more direct, fluvial origin.

The textural data indicate a clear increase upsection in grain size (Fig. 7) accompanied by a decrease in sorting (Fig. 11). Grain size reaches its first maximum and sorting its first minimum in Cores 603B-58 through -56 $(1349-1332 \mathrm{~m})$, the interval in which turbidite activity 
reaches a maximum (lower Barremian, Fig. 2). A reversal in grain size and sorting trends in the mid-Barremian follows the decline in turbidite activity from Cores 603B54 through -50 . Coarsest grain size and poorest sorting are encountered in Core 603B-46 and, in the case of grain size, in Core 603B-49 as well. These trends can be explained by the migration of a fan depocenter toward Site 603 from the late Valanginian to early Barremian, reaching a maximum in mid-Barremian, with fastest flow regimes over Site 603 in mid-Barremian. Channel switching may have resulted in finer and better-sorted sand supplied to Site 603 during the upper Barremian (Cores 603B-55 through -50). A return of major depositional activity to the old channel site may have resulted in deposition of the uppermost, unconsolidated sand unit (Cores 603B-49 through -45).

In addition, or as an alternative, the nature of the sediment supplied to Site 603 may have changed from Valanginian to Barremian. We hypothesize an initial source of very fine, well to moderately well sorted sand from Valanginian through lower Barremian that was joined by a second source of sediment for Cores 603B-58 through -56 and $603 \mathrm{~B}-49$ through -45 ; this would account for the decrease in sorting in these intervals. More rapid input of sediment in the other intervals could account for decreased sorting and increased grain size, and could be a result of continental floods. Glaser (1969) noted the importance of flooding in the deposition of the Potomac Group.

Mere fan migration toward Site 603 cannot by itself account for the mineralogic changes upcore. From Cores 603B-73 through -63 , the heavy mineral suite is dominated by zircon, apatite, and garnet, with minor amounts of epidote, staurolite, and kyanite. Cores 603B-62 through -60 have heavy mineral suites that are dominated by apatite, zircon, and epidote, with minor amounts of staurolite, kyanite, and garnet. From Cores 603B-49 through -45 , the suite is dominated by epidote, with minor amounts of zircon, apatite, garnet, staurolite, and kyanite. The heavy mineral suite in the interval from Cores 603B-58 through -50 shifts back and forth between zircon-apatite-garnet (ZAG suite) dominance and epidote dominance. These results indicate at least two separate sources supplied sediment to Site 603 during apron (or fan) development. The first source dominated deposition from Cores 603B-73 through 603B-60. It supplied well to moderately well sorted, very fine sand that has a mixed (ZAG) suite of heavy minerals. The ZAG suite predominates in Cores 603B-73 to -63. The second source was moderately well to moderately sorted fine to very fine sand enriched in epidote and sphene. Epidote and sphene are the only minerals that decrease significantly $(C=95 \%)$ with increasing fines $(r=--0.489$ and 0.434 , respectively). This source supplied most of the sediment from Cores 603B-49 through -45 . From Cores 603B-62 to -50 either source dominates or, in a few cases, there is apparently a mix of the two. For example, in Cores 603B-62 to -60, apatite levels increase, garnet levels decrease, and epidote levels begin to increase. Thus the epidote-rich source was beginning to make itself felt while the source of garnet delivered less sediment. Dur- ing maximum turbidite activity (Cores 603B-58 to -56 ), the heavy mineral suite shifts from ZAG-source dominance in Cores 603B-58 and -56 to epidote-source dominance in Core 603B-57. This interplay continues with the ZAG suite dominating in Cores 603B-56 and -50 and the epidote-rich suite dominating in Cores 603B-54 and -52 . Beginning in Core $603 \mathrm{~B}-49$, the epidote-rich source overwhelms the first and dominates for the remainder of the sequence (to Core 603B-45).

Flooding events in the source area could have brought coarser-grained, epidote-enriched upland sediment to Site 603 during maximum turbidite activity (Cores 603B-58 to -56), during deposition of the uppermost, $30-\mathrm{m}$ sand unit (Cores 603B-48 to -45), and at other times. The first flooding event would have been in the middle Hauterivian (Core 603B-66), where the first increase in epidote level is noted. Cores 603B-61 to -57 have enhanced epidote levels, possibly indicating renewed continental flooding or other type of erosive event.

The ZAG suite is probably a composite derived from more than one source. Apatite and zircon are derived from felsic igneous rocks. These minerals are significantly correlated with each other in this sediment and may have had a common source. High zircon and apatite levels are reported in separate studies from nearby localities in Virginia. Zircon-dominated mineral suites from northern Virginia (Glaser, 1969) are less than $60 \mathrm{~km}$ up-dip from apatite-rich Patuxent sediment at the Oak Grove Well (Reinhardt et al., 1980). At this site, apatite decreases from $40 \%$ of the heavy mineral suite in some Patuxent-age samples to a minor component or is absent altogether in Patapsco-age sediment. Further studies of the apatite from Site 603 , including fission track dating, will help to determine if the apatite comes from this locality. Unlike apatite and zircon, garnet is derived from high-rank metamorphic rock, and this could account for its more independent behavior (vs. zircon and apatite) in this sediment. Higher garnet levels were noted at the Oak Grove Well (Reinhardt et al., 1980) and at the COST B-2 Site (Smith, 1980). In other localities in the Salisbury Embayment, garnet is virtually absent (Glaser, 1969; Groot, 1955), indicating it may have a few point sources that contributed sediment to Oak Grove, the COST B-2 area, and to sediment that would ultimately be deposited at Site 603. Minor heavy minerals occurring with zircon, apatite, and garnet include kyanite and staurolite, which also come from high-rank metamorphic rocks. These minerals are significantly correlated with each other and thus may have a common source. Garnet is not correlated with staurolite or kyanite in this sediment and probably has a separate source. Staurolite is a major component of Patuxent sediment in most of the Salisbury Embayment, except the northern Virginia localities of Glaser (1969). If staurolite-rich, Patuxent sediment from the Salisbury Embayment supplied sediment to Site 603 , it was highly diluted by sediment from another source. Alternatively, of course, the sediment at Site 603 may not have come from the Salisbury Embayment. Staurolite is a minor component of the heavy mineral suite at the COST B-2 Well (Smith, 1980). Although kyanite is a minor component of heavy mineral suites in 
all the studies here reviewed, its presence is persistent in Patuxent sediment and virtually absent in Patapsco sediment of northern Delaware (Groot, 1955). Thus the ZAG suite is probably a composite from three sources: (1) a zircon-apatite-rich, (2) a garnet-rich, and (3) a staurolite-kyanite-rich sediment.

The epidote-rich source either had small amounts of zircon, apatite, garnet, staurolite, kyanite, and sphene or little else but epidote and sphene in its heavy suite, and merely joined the ZAG suite source. High epidote levels were reported from Hammond and Oak Grove Well sites. At the Hammond Well site, an increase in epidote levels coincides with a change from Patuxent to Patapsco sediment. Glaser (1969) suggested that epidote might come from farther north along the Atlantic coast, possibly from as far north as New England. Thus it is possible that rather than an upland, onshore source for the epidote-rich sediment, the direction of source material changed from west to northwest as fan or apron deposition progressed. However, it seems unlikely that a more distal source could enrich sediment in a single mineral. Unroofing of an epidote-rich source could account for the increase in epidote levels in younger sediment, but the early appearance of abundant epidote (Core 603B66) contradicts an unroofing hypothesis. Further studies of trace elements in the epidote should help to distinguish its source.

Perhaps the most significant parallel in the heavy mineral suites of Site 603 and those of onshore sediment is the decrease in variety of mineral species in younger sediment. In the Potomac Group, zircon levels increase from Patuxent (Hauterivian?-Barremian-Aptian?) sediment to Patapsco (Albian) sediment. Zircon levels decline from Hauterivian to Barremian sediment at Site 603 but increase again in Aptian sediment. The high staurolite levels of the Patuxent Formation are not echoed at Site 603 , but the decline of staurolite levels into younger sediment is. Upper Patuxent and lower Patapsco sediment (upper Barremian?-Aptian) are separated by an erosional unconformity onshore (e.g., Glaser, 1969), but that age sediment is present at Site 603. Patapsco-like conditions, indicated by a depauperate heavy mineral suite, first become evident shortly after maximum fan development at Site 603 (Core 603B-54) and become dominant in upper Barremian and lower Aptian sediment (Cores 603B49 to -45 ). The terrestrial conditions that resulted in the limited heavy mineral suite of Patapsco sediment include prolonged weathering, decreased rates of erosion (Groot, 1955; Glaser, 1969), and possibly higher sea-level stand. According to Vail et al. (1977), sea level was rising through the Barremian. Thus Patapsco-like conditions resulting in limited heavy mineral suites probably started to develop before the deposition of the oldest (preserved) $\mathrm{Pa}$ tapsco sediment (i.e., Barremian). A sharp drop in sea level during the Aptian could have eroded lowest onshore Patapsco sediment, resulting in the Patuxent-Patapsco unconformity and siliciclastic deposition in the deep sea. This would account for a Patapsco-like heavy mineral suite in sediment at Site 603 that is the age of the Patuxent-Patapsco unconformity, and for the $\mathrm{Pa}$ tapsco-like suite in the uppermost sand unit.

\section{CONCLUSIONS}

1. The sediment at Site 603 shows an increase in average grain size of the light mineral fraction upsection, accompanied by a decrease in sorting.

2. Maximum grain size and minimum sorting of the light mineral fraction are encountered at two intervals: during maximum turbidite activity (Cores 603B-58 to -56 ), and in the unconsolidated sand cap (Cores 603B-48 to -45 )

3. During maximum turbidite activity, the mineralogy of the heavy mineral suite shifts from a mixture of zircon, apatite, and garnet, with minor amounts of staurolite and kyanite, to epidote dominance, with minor amounts of zircon, apatite, garnet, staurolite, kyanite, and sphene.

The change in texture and mineralogy is attributed to the advent of a second source of sediment. The original source of sediment was a mixture derived from zirconapatite-rich sediment, garnet-rich sediment, and staurolite-kyanite-rich sediment. This sediment had an average grain size in the light mineral fraction of very fine to fine sand, and was well to moderately well sorted. The second source of sediment had a heavy mineral suite that was dominated by epidote, and a fine sand-sized light mineral fraction. A mixture of these two sediment types resulted in poorer sorting of sediment uphole at Site 603 . The epidote-rich source may have been derived from a more upland terrain during periods of continental flooding, thus representing a more direct continental input of sediment during maximum turbidite and sand cap emplacement.

The results indicate that conditions that resulted in a limited heavy mineral suite for Albian-age Patapsco sediment probably began much earlier, in the mid- to late Barremian. An erosional unconformity between the $\mathrm{Pa}$ tuxent and Patapsco Formations onshore is represented by a limited heavy mineral suite in the sediment at Site 603. The source for the sediment at Site 603 is probably a weathered Piedmont/Blue Ridge terrane, as well as mid-Atlantic coastal plain and continental shelf deposits.

\section{ACKNOWLEDGMENTS}

The heavy mineral separations, grain counts, and textural analyses were performed by JB. MAH ran the statistical analyses and wrote the literature review as part of her doctorate dissertation (in preparation). Laboratory support was provided by Dennis S. Cassidy of the FSU Antarctic Research Facility and an NSF Grant DPP-8414268. We thank David K. Watkins for reviewing an early draft of the manuscript, and Dennis Prezbindowski and Robert Osborne for their review of a later draft. Theresa Dunn helped with data entry, figure generation, and proofreading. Stephen Kish kindly assisted with mineral identification.

\section{REFERENCES}

Anderson, J. L., 1948. Cretaceous and Tertiary subsurface geology: the stratigraphy, paleontology, and sedimentology of three deep test wells on the Eastern Shore of Maryland. Dept. Geol. Mines Water Resources Bull. No. 2.

Davis, J. C., 1973. Statistics and Data Analysis in Geology: New York (J. Wiley \& Sons).

Doyle, J. A., and Robbins, E. I., 1977. Angiosperm pollen zonation of the continental Cretaceous of the Atlantic coastal plain and its application to deep wells in the Salisbury Embayment. Palynology, 1:43-78.

Folk, R. L., 1980. Petrology of Sedimentary Rocks: Austin, Texas (Hemphill Pub. Co.). 
Galehouse, J. S., 1971. Point counting. In Carver, R. E. (Ed.), Procedures in Sedimentary Petrology: New York (Wiley), pp. 385-408.

Glaser, J. D., 1969. Petrology and origin of Potomac and Magothy (Cretaceous) sediments, middle Atlantic Coastal Plain. Maryland Geol. Surv. Rept. Invest. No. 11.

Groot, J. J., 1955. Sedimentary petrology of the Cretaceous sediments of northern Delaware. Delaware Geol. Surv. Bull., 5:1-57.

Habib, D., 1977. Comparison of Lower and middle Cretaceous palynostratigraphic zonations in the western North Atlantic. In Swain, F. M. (Ed.), Stratigraphic Micropaleontology of Atlantic Basin and Borderlands. Developments in Paleontology and Stratigraphy. Ser. No. 6: Amsterdam (Elsevier), pp. 341-367.

Hansen, H. J., 1982. Hydrogeologic framework and potential utilization of the brine aquifers of the Waste Gate Formation, a new unit of the Potomac Group underlying the Delmarva Peninsula in Waste Gate Formation. Part One. Maryland Geol. Surv. Open File Rept., pp. 1-50.

1984. Hydrogeologic characteristics of the Waste Gate Formation, a new subsurface unit of the Potomac Group underlying the eastern Delmarva Peninsula. Maryland Geol. Survey Inf. Circ. 39.

Hinte, J. van, Wise, S. W., Jr., et al., 1985. DSDP Site 603: first deep $(>1000 \mathrm{~m})$ penetration of the continental rise along the passive margin of eastern North America. Geology, 13:392-396.

Jansa. L. F., Enos, P., Tucholke, B. E., Gradstein, F. M., and Sheridan, R. E., 1979. Mesozoic-Cenozoic sedimentary formations of the North American Basin; western North Atlantic. In Talwani, M., Hay, W., and Ryan, W.B.F. (Eds.), Deep Drilling Results in the Atlantic Ocean Continental Margins and Paleoenvironment: Washington D.C. (Am. Geophys. Union), Maurice Ewing Ser., 3: $1-57$.

Kirkpatrick, G. L., 1982. Statistical analysis of grain size data as a possible key to ancient depositional environments [M.S. dissert.]. Florida State University, Tallahassee.

Leg 93 Staff, 1983. The continental rise off North America. Nature, 305:386.

Libby-French, J., 1984. Stratigraphic framework and petroleum potential of northeastern Baltimore Canyon Trough, mid-Atlantic Outer Continental Shelf. Am. Assoc. Petrol. Geol. Bull., 68:50-73.

Nelson, C. H., and Nilsen, T. H., 1974. Depositional trends of modern and ancient deep-sea fans. In Dott, R. H., Jr., and Shaver, R.
H. (Eds.), Modern and Ancient Geosynclinal Sedimentation. Soc. Econ. Paleontol. Mineral. Spec. Publ., No. 19, Tulsa, Oklahoma, pp. 69-91.

Pettijohn, F. J., 1941. Persistence of heavy minerals and geologic age. J. Geol., 49:610-625.

Reinhardt, J., Christopher, R. A., and Owens, J. P., 1980. Lower Cretaceous stratigraphy of the core. Virginia Div. Min. Resources Publ., 20(3):31-52.

Robertson, A.H.F., and Bliefnick, D. M., 1983. Sedimentology and origin of Lower Cretaceous pelagic carbonates and redeposited clastics, Blake-Bahama Formation, Deep Sea Drilling Project Site 534, western equatorial Atlantic. In Sheridan, R. E., Gradstein, F. M., et al., Init. Repts. DSDP, 76: Washington (U.S. Govt. Printing Office), 795-828.

Rohlf, F. J., and Sokal, R. R., 1969. Statistical Tables: San Francisco (W. H. Freeman and Co.),

Scholle, P. A., 1977. Data summary and petroleum potential. In Scholle, P. A. (Ed.), Geological Studies on the COST No. B-2 Well, U.S. Mid-Atlantic Outer Continental Shelf Area. U.S. Geol. Surv. Circ. 750 , pp. 8-14.

Siemers, C. T., 1981. Sedimentological core analysis of deep water clastic sediments in the down-dip Woodbine-Eagle Ford interva (Upper Cretaceous). In Siemers, C. T., Tillman, R. W., and Williamson, C. R. (Eds.), Deep-water Clastic sediments: a Core Workshop. Soc. Econ. Paleontol. Mineral. Core Workshop No. 2, San Francisco, p. 249.

Smith, R. V., 1980. Provenance of Mid-Atlantic continental margin sediments from the COST B-2 test well [MA dissert.]. University of Delaware, Newark.

Vail, P. R., Mitchum, R. M., Jr., and Thompson, S., III, 1977. Seismic stratigraphy and global changes of sea level, Part 4: global cycles of relative changes of sea level. In Watkins, J. S., Montadert, L., and Dickerson, P. W. (Eds.), Geophysical and Geological Investigations of Continental Margins. Mem. Am. Assoc. Pet. Geol., 29:469-472.

Date of Initial Receipt: 30 July 1985

Date of Acceptance: 12 June 1986 


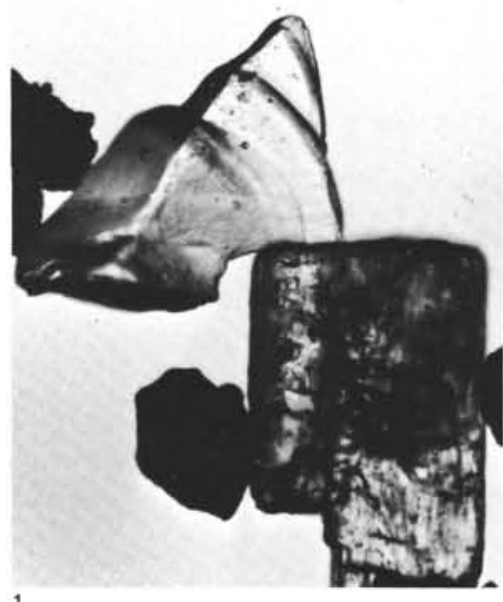

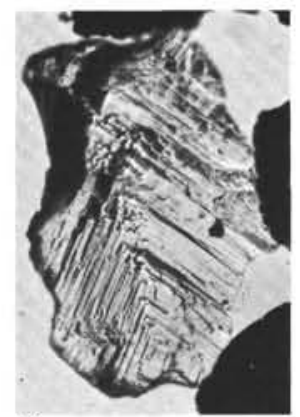

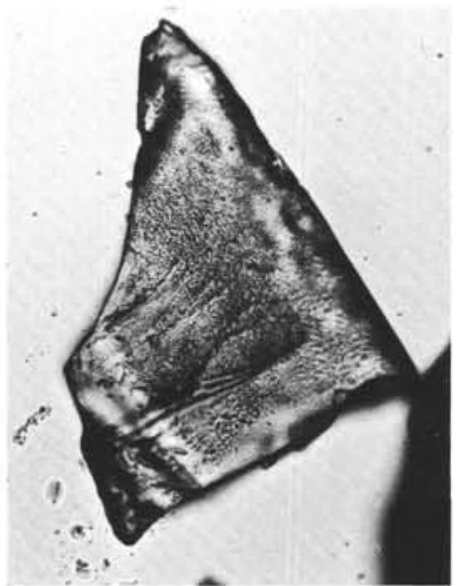

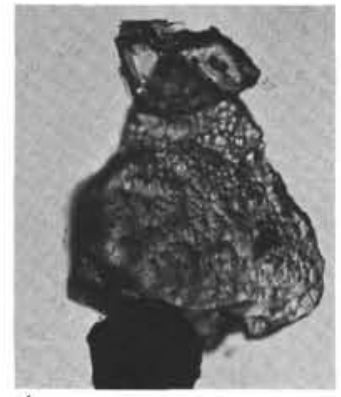
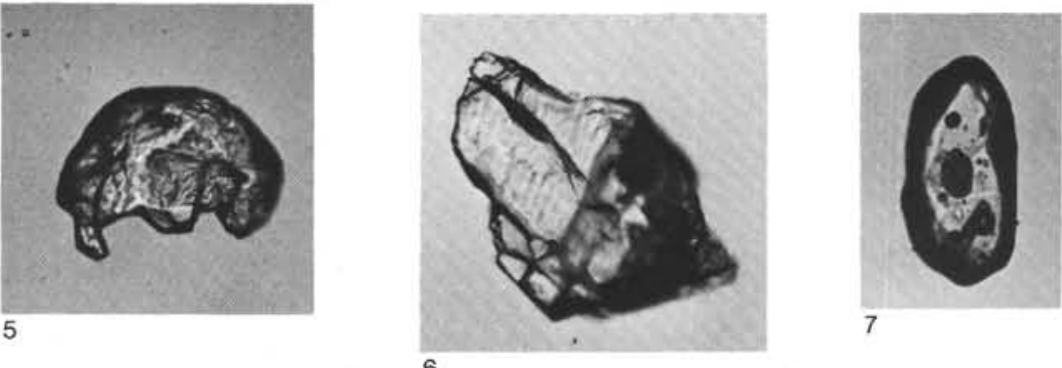

7

6

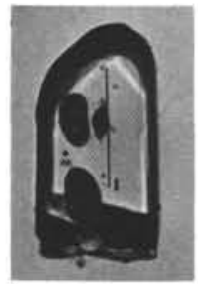

8

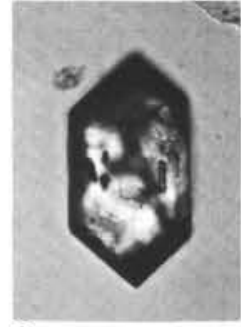

9

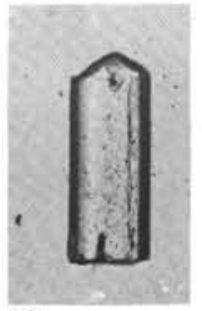

10

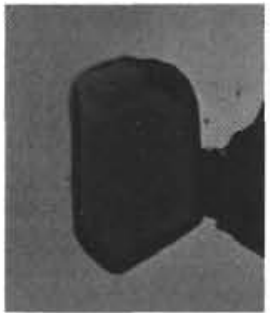

11

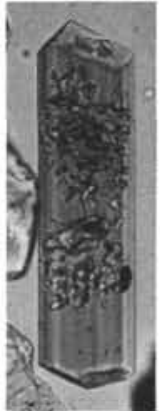

12

Plate 1. All illustrations are plane polarized light micrographs. 1. Epidote (lower right) and garnet (upper left) grains, $\times 134$, Sample $603 \mathrm{~B}-57-5$, $37-38 \mathrm{~cm}$. 2. Subangular garnet grain with extensive chemical etching that has yielded steplike, V-shaped surface features, $\times 117$, Sample $603 \mathrm{~B}-58-1,50-51 \mathrm{~cm}$. 3. Staurolite grain, $\times 236$, Sample 603B-52-5, 106-107 cm. 4. Anhedral staurolite grain with hummocky surface features caused by chemical etching, $\times 115$, Sample $603 \mathrm{~B}-63-7,16-17 \mathrm{~cm}$. 5. Anhedral, subrounded garnet grain with extensive chemical etching that has yielded the embayed surface features, $\times 116$, Sample 603B-71-1, 116-117 cm. 6. Epidote grain, $\times 132$, Sample 603B-57-5, 37-38 $\mathrm{cm}$. 7. Anhedral, subrounded zircon grain with round inclusions, $\times 149$, Sample $603 \mathrm{~B}-58-1,50-51 \mathrm{~cm}$. 8. Zircon grain, $\times 114$, Sample 603B-58-1, 50-51 cm. 9. Euhedral zircon grain with tubular inclusions, $\times 112$, Sample 603B-63-7, 16-17 cm. 10. Apatite grain, $\times 116$, Sample 603B-50-1, 113-114 cm. 11. Subrounded euhedral tourmaline grain, $\times 118$, Sample 603B-63-7, 16-17 cm. 12. Euhedral tourmaline grain with etched surface features, $\times 183$, Sample $603 \mathrm{~B}-63-7,16-17 \mathrm{~cm}$. 